\title{
Enhanced detection of nucleotide repeat mRNA with hybridization chain reaction
}

\section{Authors: M. Rebecca Glineburg ${ }^{1}$, Yuan Zhang ${ }^{1,2}$, Elizabeth Tank ${ }^{1}$, Sami Barmada1 and Peter K Todd ${ }^{1,3}$}

\section{Affiliations:}

1) Department of Neurology, University of Michigan, Ann Arbor, MI, USA

2) Department of Respiratory Medicine, Xiangya Hospital, Central South University, Changsha, China. 410008.

3) Veterans Affairs Medical Center, Ann Arbor, MI, USA

Contact:

Petertod@umich.edu

4005 BSRB

109 Zina Pitcher Place

Ann Arbor, Ml 48109-2200

USA

Running title: HCR detection of expanded repeats

Key words: C9ORF72, Amyotrophic Lateral Sclerosis, Fragile X, FXTAS, repeatassociated non-AUG (RAN) translation, RNA Gelation, RNA foci, stress granules, G3BP. 


\section{ABSTRACT}

RNAs derived from expanded nucleotide repeats form detectable foci in patient cells and these foci are thought to contribute to disease pathogenesis. The most widely used method for detecting RNA foci is fluorescence in situ hybridization (FISH). However, FISH is prone to low sensitivity and photo-bleaching that can complicate data interpretation. Here we applied hybridization chain reaction (HCR) as an alternative approach to repeat RNA foci detection of GC-rich repeats in two neurodegenerative disorders: GGGGCC $\left(\mathrm{G}_{4} \mathrm{C}_{2}\right)$ hexanucleotide repeat expansions in C9orf72 that cause amyotrophic lateral sclerosis and frontotemporal dementia (C9 ALS/FTD) and CGG repeat expansions in FMR1 that cause Fragile X-associated tremor/ataxia syndrome. We found that $\mathrm{HCR}$ of both $\mathrm{G}_{4} \mathrm{C}_{2}$ and $\mathrm{CGG}$ repeats has comparable specificity to traditional FISH, but is $>40 \mathrm{x}$ more sensitive and shows repeat-length dependence in its intensity. HCR is better than FISH at detecting both nuclear and cytoplasmic foci in human C9 ALS/FTD fibroblasts, patient iPSC derived neurons, and patient brain samples. We used HCR to determine the impact of integrated stress response (ISR) activation on RNA foci number and distribution. $\mathrm{G}_{4} \mathrm{C}_{2}$ repeat RNA did not readily co-localize with the stress granule marker G3BP1, but ISR induction increased both the number of detectible nuclear RNA foci and the nuclear/cytoplasmic foci ratio in patient fibroblasts and patient derived neurons. Taken together, these data suggest that HCR can be a useful tool for detecting repeat expansion mRNA in C9 ALS/FTD and other repeat expansion disorders. 


\section{INTRODUCTION}

GC-rich repeat expansions are the genetic cause of over 50 neurodevelopmental, neurodegenerative, and neuromuscular diseases. Repeat expansions elicit disease through multiple mechanisms (reviewed in Orr and Zoghbi 2007; Rodriguez and Todd 2019). Repeats as DNA can inhibit transcription of repeat-containing genes and promote the DNA damage response through R-loop formation (Tuduri et al. 2009; Reddy et al. 2011; Reddy et al. 2014; Groh et al. 2014; Haeusler et al. 2014). Repeats as RNA can functionally sequester both canonical and non-canonical RNA binding proteins and prevent them from performing their normal functions (Miller et al. 2000; Mankodi et al. 2000; Jin et al. 2007; Cooper-Knock et al. 2014; Conlon et al. 2016; Lee et al. 2013; reviewed in Rodriguez and Todd 2019; Swinnen, Robberecht, and Van Den Bosch 2020; Johnson and Cooper 2021). Repeats can also be translated into toxic proteins, either via canonical translation (as occurs for a number of polyglutamine expansions) or via repeat associated non-AUG (RAN) initiated translation (Zu et al. 2011; Todd et al. 2013; Green et al. 2017; Kearse et al. 2016; Paulson et al. 1997; Trottier et al. 1995; La Spada et al. 1991).

One of the key pathological hallmarks in repeat expansion diseases is the presence of repeat-containing RNA foci. These foci are thought to represent repeat RNAs coassociated with specific RNA binding proteins, although they may also arise from intraand inter- molecular RNA-RNA interactions via RNA gelation (Jain and Vale 2017; Fay, Anderson, and Ivanov 2017; Mankodi et al. 2001; Fardaei et al. 2002; Tassone, Iwahashi, and Hagerman 2004; Iwahashi et al. 2006; Jin et al. 2007; Sofola et al. 2007; Sellier et al. 2010; Sellier et al. 2013; Bajc Cesnik et al. 2019). The exact behavior, biophysical properties, and associated protein and RNA factors of these RNA condensates varies across different repeat expansions (reviewed in Nussbacher et al. 2019; Echeverria and Cooper 2012; Johnson and Cooper 2021). Traditionally, these foci are visualized by fluorescent in situ hybridization (FISH) (Figure 1A) (Urbanek and Krzyzosiak 2016; Lee et al. 2013; Urbanek, Michalak, and Krzyzosiak 2017; Hoem et al. 2011; Verma et al. 2019; Jin et al. 2007). Because of the repetitive nature of the 
repeat, single probes to the repeat region can "tile" along the mRNA and enhance signal detection, early studies were able to successfully identify these foci. However, $\mathrm{FISH}$ in human tissues has remained hindered by the low abundance of these repeat containing RNAs, and high background due to the human transcriptome containing numerous GC rich repeats (Sulovari et al. 2019; Saxonov, Berg, and Brutlag 2006; Yamashita et al. 2005; Kozlowski, de Mezer, and Krzyzosiak 2010; DeJesusHernandez et al. 2011; Belzil et al. 2013; Urbanek and Krzyzosiak 2016; Didiot et al. 2018).

Recently, a more sensitive method, hybridization chain reaction (HCR) was developed that uses an initiator probe recognizing the RNA of interest and a pair of hairpin probes conjugated with fluorophores to amplify the initiator signal (Figure 1B) (Choi et al. 2018; Choi, Beck, and Pierce 2014a, 2014b; Choi et al. 2011). This approach significantly amplifies the signal of an individual molecule over traditional FISH and makes it easier to detect low abundant RNAs, while also reducing background signal. Here, we utilized HCR to detect RNA foci associated with GGGGCC repeat expansions in C9orf72 that are the most common genetic cause of ALS and FTD and CGG repeats associated with Fragile $X$ disorders such as Fragile $X$-associated tremor/ataxia syndrome (FXTAS) (Hagerman et al. 2001; Renton et al. 2011; DeJesus-Hernandez et al. 2011). HCR provided significantly higher sensitivity for detection of repeats and allowed accurate tracking of endogenous GGGGCC repeat RNAs in patient cells in response to cellular stress activation. Taken together, these data suggest that HCR can be a valuable addition to analysis and imaging pipelines in repeat expansion disorders.

\section{Results}

\section{HCR is more sensitive than FISH for GC rich repeats}

We first compared the sensitivity and specificity of traditional FISH vs HCR probes. We designed fluorophore labeled locked nucleic acid (LNA) $\left(\mathrm{C}_{4} \mathrm{G}_{2}\right)_{6}$ and $(\mathrm{CCG})_{8} \mathrm{FISH}$ probes and $\left(\mathrm{C}_{4} \mathrm{G}_{2}\right)_{6}$ and $(\mathrm{CCG})_{10} \mathrm{HCR}$ initiator probes to hybridize to corresponding $\mathrm{G}_{4} \mathrm{C}_{2}$ or $\mathrm{CGG}$ repeats. Alexa fluorophore labeled amplifier hairpin probes $\mathrm{B} 1 \mathrm{H} 1$ and 
$\mathrm{B} 1 \mathrm{H} 2$ were then used to amplify the HCR probe signal (Figure $1 \mathrm{~A}-\mathrm{B}$, Supplemental table 2) (Choi, Beck, and Pierce 2014b; Choi et al. 2011). We conducted a side-byside comparison in mouse embryonic fibroblasts (MEFs) expressing $\left(\mathrm{G}_{4} \mathrm{C}_{2}\right) 70-\mathrm{NL}-$ 3xFlag or (CGG)100-3xFlag reporters (Green et al. 2017; Kearse et al. 2016). We found more repeat positive cells by HCR than FISH when using the same probe concentration (8nM) (Figure 1C-D). When we further increased each FISH probe concentration to $64 \mathrm{nM}$, we only saw a modest increase in number of repeat positive cells that remained significantly lower than that seen using HCR. In contrast, when we decreased each HCR probe concentration to $4 \mathrm{nM}$ and $0.8 \mathrm{nM}$, we still observed enhanced signal compared to $\mathrm{FISH}$, for both $\mathrm{G}_{4} \mathrm{C}_{2}$ and $\mathrm{CGG}$ repeats (Figure $1 \mathrm{C}-\mathrm{D}$ ). Furthermore, both nuclear and cytoplasmic signal was readily detected using HCR, while FISH primarily detected only the stronger nuclear signal. No signal was detected by either method in MEFs not expressing $\mathrm{G}_{4} \mathrm{C}_{2}$ or $\mathrm{CGG}$ repeats (Figure 1C-D). Together, these results show that HCR is more sensitive than FISH for detecting exogenous GC rich repeats.

To confirm that the observed signal from HCR was due to probe hybridization to RNA and not DNA, we treated the $\left(\mathrm{G}_{4} \mathrm{C}_{2}\right) 70$ and $(\mathrm{CGG}) 100$ transfected MEFs with DNase or RNase prior to HCR. While DNase robustly eliminated DAPI signal, it had no effect on the GC-rich repeat signal. Conversely, almost all probe signal went away when cells were treated with RNase (Figure 1E). To further validate that our HCR probes were specifically recognizing their target RNA, we transfected cells with antisense CCCCGG (ATG-(C $\left.\left.{ }_{4} \mathrm{G}_{2}\right) 47-\mathrm{NL}-3 x \mathrm{Flag}\right)$ or CCG ((CCG)60-NL-3xFlag) reporters. We did not detect any repeat signal in Flag positive cells (Figure 1F). Together this supports that our HCR probes specifically hybridize to $\mathrm{G}_{4} \mathrm{C}_{2}$ and $\mathrm{CGG}$ repeat containing RNA, with high specificity and sensitivity.

We next determined whether HCR could distinguish between different $\mathrm{G}_{4} \mathrm{C}_{2}$ repeat sizes (3, 35, or $70 \mathrm{G}_{4} \mathrm{C}_{2}$ repeats). Despite similar transfection efficiencies among all three conditions (as monitored by GFP co-transfection, Supplemental Figure 1A-C), 
we observed no signal in cells expressing $\left(\mathrm{G}_{4} \mathrm{C}_{2}\right)_{3}-\mathrm{NL}-3 x \mathrm{Flag}$. The number of HCR positive cells was comparable for both $\left(\mathrm{G}_{4} \mathrm{C}_{2}\right)_{35}-\mathrm{NL}-3 x \mathrm{Flag}$ and $\left(\mathrm{G}_{4} \mathrm{C}_{2}\right)_{70} \mathrm{NL}-3 \mathrm{xFlag}$ transfection (Figure 2A-B). However, there was a significant correlation between HCR signal intensity and repeat length, with $\left(\mathrm{G}_{4} \mathrm{C}_{2}\right)_{70}-\mathrm{NL}-3 x$ Flag transfected cells having higher HCR signal intensity (Figure 2C).

We next performed similar experiments in cells transfected with CGGn-NL-3xFlag reporters with repeats of various length $(24,55$, and 100 CGG repeats). We observed a strong positive correlation between CGG repeat length and the number of HCR positive cells (Figure 2D-E). We also observed a significant increase in HCR signal intensity within cells expressing longer CGG repeats (Figure 2D \& F). CGG repeat expansions within the FMR1 5'UTR have previously been shown to enhance transcription, and we and others have observed a positive correlation of repeat length and RNA abundance in this setting (Chen et al. 2003; Khateb et al. 2007 and unpublished data). Thus, this repeat-length increase in HCR signal could result from enhanced mRNA production as well as more CGG repeat binding sites in the longer repeat reporters. As both repeat size and expression are tightly linked to disease, we believe HCR can be used to qualitatively assess CGG repeat RNA burden in model systems.

\section{HCR is more sensitive in detecting endogenous repeat signal than FISH}

We next determined if HCR was effective at detecting endogenous GC-rich repeat RNA. We first compared HCR and FISH in control and C9orf72 patient fibroblasts. Unlike in transiently transfected cells where RNA signal via HCR was predominantly globular and nuclear, endogenous $\mathrm{G}_{4} \mathrm{C}_{2}$ repeats appear primarily as small foci, similar to foci detected by FISH. Previous studies observed upwards of $35 \%$ of C9orf72 patient fibroblasts contained at least $1 \mathrm{G}_{4} \mathrm{C}_{2}$ repeat foci (Liu et al. 2017), although signal specificity was not established. Here, after normalizing to control fibroblast signal, we observed only half the number of $\mathrm{G}_{4} \mathrm{C}_{2}$ repeat positive cells previously reported in three different expansion cell lines (C9-C1, C9-C2, C9-C3). However, our 
number of foci/foci positive cell is in agreement with previously published work (Figure 3E) (Liu et al. 2017; DeJesus-Hernandez et al. 2017). Using HCR, we detected $>2 x$ more $\mathrm{G}_{4} \mathrm{C}_{2}$ positive cells than with FISH (Figure $3 A-B, D$ ). Importantly, we also observed a significant increase in the number of foci/foci positive cell (Figure 3E). Intriguingly, while $\mathrm{FISH}$ primarily detected foci in the nucleus of $\mathrm{G}_{4} \mathrm{C}_{2}$ repeat expansion cell lines, $\mathrm{HCR}$ was able to detect cytoplasmic foci in $\sim 40 \%$ of $\mathrm{G}_{4} \mathrm{C}_{2}$ repeat positive cells (Figure 3F). Previous studies observed cytoplasmic foci only $\sim 10 \%$ of the time (Mizielinska et al. 2013). To confirm that the signal we were observing was from RNA, we treated the $\mathrm{G}_{4} \mathrm{C}_{2}$ repeat expansion fibroblasts with DNase or RNase before HCR and found the HCR signal was sensitive to RNase and resistant to DNase (Figure 3C).

We next compared FISH and HCR in control and C9orf72 patient brain tissue. We looked for foci in cerebellum and frontal cortex, as those regions have been previously shown to have $\mathrm{G}_{4} \mathrm{C}_{2}$ repeat RNA foci and feature evidence of disease pathology (DeJesus-Hernandez et al. 2017; Mizielinska et al. 2013). After normalizing signal to controls, we detected $\mathrm{G}_{4} \mathrm{C}_{2}$ repeat positive cells from three of the C9 brains (C9-B1, C9-B2 and C9-B3) using FISH. However, signal was only detected in about $1 \%$ of cells. In contrast, when HCR was performed on these same brain samples, more than $30 \%$ of cells were positive for $\mathrm{G}_{4} \mathrm{C}_{2}$ repeat RNA (Figure $4 A-B, D$ ). These foci were absent when tissue was RNase treated, and remained when tissue was DNase treated, strongly supporting that these are RNA foci (Figure 4C). Together, these data indicate that HCR can be useful in detection of low abundant endogenous $\mathrm{G}_{4} \mathrm{C}_{2}$ repeat RNA.

We performed a similar experiment in control and FXTAS patient fibroblasts. With the sense CGG repeat HCR probe, we found CGG repeat signal was readily detectable not only in FXTAS patient cells lines, but also in premutation carriers and control lines. The pattern of the detected signal appeared predominantly nucleolar similar to prior reports in FXTAS brain tissue (Tassone, Iwahashi, and Hagerman 2004; Sellier et al. 2013; Sellier et al. 2010). We did not observe any HCR signal in these same cell lines when we used the antisense CCG repeat HCR probe or after RNAse treatment, 
suggesting this signal was primarily CGG RNA-mediated (Supplemental Figure 2A). These results indicate that the CGG repeat signals are CGG RNA-specific but not FMR1 CGG repeat expansion-specific. We next evaluated HCR on CGG repeats in frontal cortex and hippocampal sections as these have been previously shown to express the CGG RAN product, FmrpolyG (Krans et al. 2019). Similar to fibroblasts, we observed nucleolar-like staining in both control and FXTAS patient brain tissue with both the CGG FISH and HCR probes. However, the signal was stronger and occurred in a higher percentage of neurons in FXTAS samples (Supplemental Figure 2B).

As the control cell lines still contain $\sim 20-30$ CGG repeats, we reasoned that the probe could still be specifically binding to FMR1 RNA. To investigate this further, we performed HCR in a transcriptionally silenced FXS iPSC line with 800 repeats, a control iPSC line with $\sim 30$ CGG repeats and then compared their signal intensity to an unmethylated full mutation line (TC-43) with a large (270) transcriptionally active CGG repeat expansion that supports RAN translation (Haenfler et al. 2018; Rodriguez et al. 2020). We observed significant staining with the CGG HCR probe in all three cell lines that was both diffuse in the cytoplasm, as well as localized to the nucleolus (Supplemental Figure 2C) However, similar to observations in FXTAS brain, we saw enhanced signal in the unmethylated full mutation line compared to the WT and methylated FXS line, suggesting that this enhanced signal was due to CGG repeat expansions within FMR1 (Supplemental Figure 2C-E).

\section{G4C2 repeats accumulate in the nucleus in response to cellular stress}

The ability to readily detect endogenous nuclear and cytoplasmic $\mathrm{G}_{4} \mathrm{C}_{2}$ repeat RNA foci using HCR is potentially useful for exploring its roles in disease pathogenesis. Our lab and others have observed that expression of $\mathrm{G}_{4} \mathrm{C}_{2}$ repeat containing reporters induces stress granule (SG) formation and the integrated stress response (ISR), and considerable evidence now suggests that this process can contribute to neurodegeneration (Green et al. 2017; Sonobe et al. 2018; Zhang et al. 2018; Li et al. 2013). Moreover, exogenous ISR activation through a variety of methods triggers a 
selective enhancement of RAN translation from both $C G G$ and $\mathrm{G}_{4} \mathrm{C}_{2}$ repeats in transfected cells and neurons (Green et al. 2017; Westergard et al. 2019; Sonobe et al. 2018; Cheng et al. 2018). To investigate the behavior of endogenous $\mathrm{G}_{4} \mathrm{C}_{2}$ repeat RNA and foci in response to stress, we treated C9orf72 patient fibroblasts with sodium arsenite (SA) or vehicle. SA treatment for one or two hours led to significant increase in the total number of cells with visible $\mathrm{G}_{4} \mathrm{C}_{2}$ repeat foci. Moreover, there was a marked re-distribution of these foci into the nucleus and out of the cytoplasm (Figure 5A-C). This same SA-induced nuclear re-distribution of $\mathrm{G}_{4} \mathrm{C}_{2}$ repeat foci was also observed in C9orf72 patient derived neurons (Figure 6A-C).

RNAs typically move into SGs and become translationally silenced in response to SA stress (Kedersha et al. 2005). In contrast, $\mathrm{G}_{4} \mathrm{C}_{2}$ repeat RNAs remain translationally competent after stress induction. We therefore assayed whether $\mathrm{G}_{4} \mathrm{C}_{2}$ repeat RNA foci localized to SGs in response to stress. Consistent with their retained translational competency, we did not observe significant co-localization of $\mathrm{G}_{4} \mathrm{C}_{2}$ repeat foci with the SG marker, G3BP1 (Figure 7A-B), although rare co-localization events were observed.

Integrated Stress response activation induces the formation of nuclear stress bodies. These TDP-43 positive structures are thought to contribute to ALS disease pathogenesis (Wang et al. 2020). Given the greater nuclear distribution of $\mathrm{G}_{4} \mathrm{C}_{2}$ repeat RNA after stress induction, we evaluated whether there was any significant overlap between endogenous $\mathrm{G}_{4} \mathrm{C}_{2}$ repeat RNA and TDP43, a critical factor in C9orf72 pathology and ALS pathogenesis as well as a robust marker for nuclear bodies (Duan et al. 2019; Wang et al. 2020). Our untreated C9 fibroblasts appeared to have small TDP-43 nuclear bodies, indicative of them being inherently stressed. Upon 2 hours of SA induction we saw a decrease in diffuse nuclear TDP43, and an increase in TDP43 nuclear foci size. Overall, nuclear TDP-43 showed limited (0.38-4.49\%) colocalization with $\mathrm{G}_{4} \mathrm{C}_{2}$ repeat RNA foci at baseline. After SA induction, there was a significant increase in this co-localization, but it remained modest $(2.56 \% \sim 8.35 \%)$ (Figure 7C-D). Taken together, these studies suggest that nuclear retention or re- 
distribution of $\mathrm{G}_{4} \mathrm{C}_{2}$ repeat RNA foci in C9orf72 fibroblasts in response to stress is not predominantly driven by either SG or nuclear body association and may instead reflect nucleocytoplasmic transport defects elicited by stress pathway activation (Mahboubi et al. 2013; Zhang et al. 2018; Burgess et al. 2011; Patterson, Wood, and Schisa 2011).

\section{Discussion:}

Repeat RNA and the formation of RNA-protein and RNA-RNA condensates are thought to act as significant factors in the pathogenesis of multiple repeat expansion disorders. However, traditional detection techniques such as FISH are often limited in their sensitivity which may cloud the roles of such repeat RNAs in disease-relevant processes. Here we used a highly sensitive RNA in situ amplification method, HCR, to readily detect low expressing endogenous GC-rich repeat expansions in both patient cells and tissues. This non-proprietary method provided significantly enhanced sensitivity over RNA FISH probes with retained specificity. This increased sensitivity allowed for greater detection and appreciation of nuclear and cytoplasmic foci in patient cells. Moreover, we demonstrated that G4C2 repeat RNA foci accumulate in the nucleus in both patient fibroblasts and neurons in response to cellular stress. This tool should prove useful to the field in explorations of endogenous repeat RNA behaviors and pathology in both repeat expansion disorders and model systems.

Previously established techniques for detecting RNA in situ have limitations. FISH is limited by RNA copy number, and probe specificity, while the use of MS2 and PP7 binding sites to detect low abundant RNAs is only applicable to exogenous gene expression, or in cases where these tags were inserted via CRISPR (Tantale et al. 2016; Spille et al. 2019; Ferguson and Larson 2013; Young, Jackson, and Wyeth 2020). Recently, an alternative RNA in situ amplification method, Basescope ${ }^{\mathrm{TM}}$, was shown to improve detection of endogenous $\mathrm{G}_{4} \mathrm{C}_{2}$ repeats in patient tissue (Mehta et al. 2020). HCR and Basescope ${ }^{T M}$ are comparable on a number of fronts. Namely, they both can be combined with IHC, have extensive signal amplification capacity, and in the case of newer HCR versions, utilize split probes to eliminate nonspecific signal (Choi et al. 
2018). However, HCR lends itself as a more universally applicable approach for a number of reasons, including minimal optimization needed, fewer steps involved, flexibility in probe stringency, and the use of fluorescent probes to allow for combined HCR-IF with multiple probes and/or antibodies. Furthermore, unlike Basescope ${ }^{T M}$, HCR v2 reagents are not proprietary, allowing for in-house production and lower cost. However, while the flexibility of fluorescent probe choice makes HCR more adaptable in a variety of experimental settings, the chromogenic properties of Basescope ${ }^{\mathrm{TM}}$ may allow for better coupling with tissue stains for pathology purposes. Thus, both serve as valuable tools for detecting and investigating endogenous GC-rich repeats.

While both HCR and Basescope ${ }^{T M}$ are sensitive tools for detecting $\mathrm{G}_{4} \mathrm{C}_{2}$ repeat RNA, we do caution the use of these techniques for detecting CGG repeat RNA. Given the extensive use of CGG RNA FISH probes in the literature, we were surprised to find such high background signal, specifically in control and FXS human samples. The staining pattern with the CGG probe was also vastly different from the foci typically observed for GC-rich repeat expansions. In fibroblasts, brain samples, and HEK293 cells we observed intense, large nuclear body staining, while iPSCs had weaker nuclear body staining and strong, diffuse cytoplasmic staining. This pattern is largely consistent with prior work using FISH to assay CGG repeat RNA in FXTAS (Sellier et al. 2013; Sellier et al. 2010). That lack of punctate RNA foci makes it difficult to determine what signal is specific to the CGG repeat expansion on FMR1. There are 921 human genes which contain $\geq 6$ CGG repeats, and this likely accounts for the high background in human cells (Haenfler et al. 2018; Kozlowski, de Mezer, and Krzyzosiak 2010). Future studies using probes to more specific regions of FMR1 are needed.

Our HCR $\mathrm{G}_{4} \mathrm{C}_{2}$ probe exhibited significantly better sensitivity and specificity in human cells and tissues. The increased sensitivity of HCR over FISH with this probe allowed us to consistently visualize $\mathrm{G}_{4} \mathrm{C}_{2}$ repeat RNA in the cytoplasm, allowing us to ask questions regarding $\mathrm{G}_{4} \mathrm{C}_{2}$ repeat RNA activities in different subcellular compartments. As a proof of concept, we analyzed $\mathrm{G}_{4} \mathrm{C}_{2}$ repeat cellular localization during stress. We 
observed no significant co-localization with $S G s$, but instead, a redistribution of $\mathrm{G}_{4} \mathrm{C}_{2}$ foci into the nucleus. This redistribution could either be caused by an increase in nuclear import, a decrease in nuclear export, or a retention of repeat RNA within subnuclear compartments. Nucleocytoplasmic transport is inhibited basally in many neurodegenerative conditions, including C9orf72 ALS/FTD (Rossi et al. 2015). Nucleocytoplasmic transport proteins, including importin-alpha, RanGap and nucleoporins are also recruited into SGs and co-localize with TDP-43 in ALS/FTD mutant cytoplasmic aggregates (Chou et al. 2018; Gasset-Rosa et al. 2019). SG assembly itself inhibits nucleocytoplasmic transport by sequestering factors required for nuclear export, and thus the increased abundance of $\mathrm{G}_{4} \mathrm{C}_{2}$ repeat RNA may be indicative of global nuclear mRNA retention (Mahboubi et al. 2013; Zhang et al. 2018; Burgess et al. 2011; Patterson, Wood, and Schisa 2011). $\mathrm{G}_{4} \mathrm{C}_{2}$ repeat RNA itself is also implicated in nuclear import perturbations via binding to RanGap1 (Zhang et al. 2015), suggesting that its nuclear retention could be not only a cause of but also a contributor to stress-dependent pathology.

Alternatively, repeat RNAs may interact with nuclear stress bodies. These complexes result from nuclear re-localization of heat shock factors, including HSF1 and HSP70, as well as RNA factors, including TDP-43, with satellite III repeat RNAs (Udan-Johns et al. 2014; Metz et al. 2004; Frottin et al. 2019; Yu et al. 2020). We observed a significant increase in co-localization between nuclear TDP-43 and $\mathrm{G}_{4} \mathrm{C}_{2} \mathrm{RNA}$. However, the overall overlap between these two molecules remained modest and of unclear biological significance.

In sum, we describe the application of HCR to the detection of endogenous GC rich repeat RNA. This non-proprietary tool is sensitive, specific and useful in studying endogenous repeat RNA foci dynamics and should prove useful for investigators interested in the behavior of these disease-associated RNA species.

\section{Methods}


1) Cell lines culture and Clinical Specimens

MEFs were received from Randal Kaufman (Sanford Burnham Prebys Medical Discovery Institute).and cultured in RPMI1640 with 10\% fetal bovine serum (FBS) and $1 \%$ penicillin/streptomycin (P/S). FXTAS skin fibroblasts were from Paul Hagerman (UC Davis) and University of Michigan donors. C9orf72 ALS/FTD skin fibroblasts are from Eva Feldman (University of Michigan). Human derived skin fibroblasts were cultured in high glucose DMEM with 10\% FBS, $1 \%$ non-essential amino acid (NEAA) and $1 \% \mathrm{P} / \mathrm{S}$. All cells were cultured at $37^{\circ} \mathrm{C}$. Control and FXTAS human brain paraffin sections were obtained from the University of Michigan Brain Bank and are previously described (Todd et al. 2013; Krans et al. 2019). Human derived neurons were generated and differentiated from Elizabeth Tank. Human derived iPSCs were generated and differentiated from Geena Skariah. Details on these specimens were presented in Supplemental Table 1.

\section{2) Reporters}

The RAN translation reporters 2(CGG) $n-N L-3 x F,\left(G_{4} \mathrm{C}_{2}\right) n-N L-3 x F l a g$, and (CCG)60-NL3xF were previously published (Kearse et al. 2016; Green et al. 2017; Krans et al. 2019). The $\left(\mathrm{G}_{2} \mathrm{C}_{4}\right)_{47}$-NL-3xFlag reporter was made by cloning the reporter sequence between Nhel and PspOMI in pcDNA3.1+ (Supplemental Table 3). The FMRpolyG ${ }_{100}-$ RAN translation reporters was made by cloning in the reporter sequence into pcDNA3.1+ between BamHI and PspOMI (Supplemental Table 3).

\section{3) Transfection}

MEFs were transfected according to manufacturer's protocol (114-15, Polyplus transfection). In brief, MEFs were suspended and incubated with3:1 Jetprime to 0.25 $\mu \mathrm{g}$ plasmid DNA at $37^{\circ} \mathrm{C}$ for 20 minutes, then seeded to chamber slides. Cells were fixed 24 hours later for ICC-HCR.

\section{4) Stress treatment}

Fibroblasts and neurons were treated with 500nM sodium arsenite (SA) or vehicle $\left(\mathrm{H}_{2} \mathrm{O}\right)$ at indicated time points then washed $1 \mathrm{x}$ in PBS and fixed for ICC-HCR.

\section{5) ICC}

The ICC was performed after fixing cells and prior to performing $\mathrm{HCR}$, using a modified protocol to one previously described. In brief, following a fix in 4\% PFA, cells were further fixed $\mathrm{O} / \mathrm{N}$ in $70 \%$ ethanol, and rehydrated with $1 \mathrm{xPBS}$ for 1 hour, prior to addition of antibodies. Cells were then fixed again in 4\% PFA for 10 minutes following the final washes after the secondary to fix the secondary antibodies in place. The following antibodies were used: Flag M2 (1:100, F1804, Sigma), GFP (1:500, ab6556, 
abcam), G3BP1(1:200, BDB611127, BD Bioscience/Fisher), TDP43(1:100, 10782-2AP, Protein Tech), Alexa Fluor 488 goat anti-mouse IgG (1:500, A11029, Invitrogen) and anti-rabbit IgG (1:500, A11008, Invitrogen).

5) FISH

Fluorophore TYE665 labeled locked nuclear acid (LNA) $\left(\mathrm{C}_{4} \mathrm{G}_{2}\right)_{6}$ and $(\mathrm{CCG})_{8}$ probes (Supplemental table 2) were synthesized by Qiagen. The FISH protocol was adapted from (DeJesus-Hernandez et al. 2017) and used HCR buffers (Choi, Beck, and Pierce 2014b; Choi et al. 2011). In brief, MEFs and fibroblasts, were washed with 1x PBSMC, fixed in 4\% PFA for $10 \mathrm{~min}$, washed 3 times with 1x PBS and permeabilized in $0.1 \%$ TritonX-100 for $15 \mathrm{~min}$. Cells were washed with $1 \mathrm{x}$ PBS, then dehydrated with $70 \%$ ethanol for $1 \mathrm{~min}, 95 \%$ for $2 \mathrm{~min}$, then $100 \%$ twice for $2 \mathrm{~min}$. Cells were air-dried, then preheated at corresponding hybridization temperature (see below) in probe hybridization buffer ( $50 \%$ formamide, $5 x$ sodium chloride sodium citrate (SSC), $9 \mathrm{mM}$

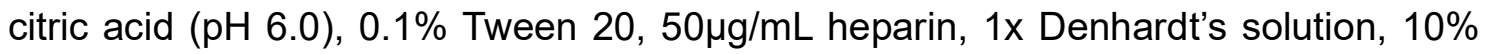
dextran sulfate) for $30 \mathrm{~min}$. The FISH probes were denatured at $80^{\circ} \mathrm{C}$ for $2 \mathrm{~min}$ before immediately snap cooling in cold hybridization buffer to prevent intermolecular annealing. Cells were incubated in hybridization buffer with $8 \mathrm{nM}, 32 \mathrm{nM}$ or $64 \mathrm{nM}$ probes at $71^{\circ} \mathrm{C}$ for $\left(\mathrm{C}_{4} \mathrm{G}_{2}\right)_{6}$ and $66^{\circ} \mathrm{C}$ for $(\mathrm{CCG})_{8}$ for $12-16 \mathrm{hrs}$, washed 4 times for $5 \mathrm{~min}$ in 5xSSCT (5x SSC, $0.1 \%$ Tween 20 ) at room temperature (RT), then mounted with ProLong Gold antifade mountant with DAPI.

For human brain paraffin sections, slides were first deparaffinized with xylenes and then rehydrated from $100 \%$ ethanol, $95 \%$ ethanol, $70 \%$ ethanol, $50 \%$ ethanol to DEPC treated $\mathrm{H}_{2} \mathrm{O}$. Rehydrated slides were incubated in $0.3 \%$ Sudan black for 5 min followed by proteinase $\mathrm{K}$ treatment at RT for $10 \mathrm{~min}$. Permeabilization, preheating, hybridization with probes, washing and mounting are the same as above.

\section{6) HCR}

The initiator probes (CCCCGG)6 and (CCG) 10 , were synthesized by OligolDT. The fluorophore 647 labeled hairpin probes $(\mathrm{B} 1 \mathrm{H} 1$ and $\mathrm{B} 1 \mathrm{H} 2)$ (Choi, Beck, and Pierce 2014b) were synthesized by Molecular Instruments. For transfected MEFs and fibroblasts, cells processed according to Molecular Instrument's protocol. In brief, cells were fixed in $70 \%$ cold ethanol overnight at $4{ }^{\circ} \mathrm{C}$. When $\mathrm{HCR}$ was performed following ICC, this step occurred prior to ICC.,Cells were then preheat in hybridization buffer at $45^{\circ} \mathrm{C}$ for $30 \mathrm{~min}$, and incubated with $0.8 \mathrm{nM}, 4 \mathrm{nM}$ or $8 \mathrm{nM}$ initiator probe ( (CCCCGG)6 or (CCG) 10 ) at $45^{\circ} \mathrm{C}$ incubator overnight. Cells were washed 4 times for 5 minutes each with pre-warmed probe wash buffer (50\% formamide, 5x SSC, $9 \mathrm{mM}$ citric acid ( $\mathrm{pH} 6.0), 0.1 \%$ Tween $20,50 \mu \mathrm{g} / \mathrm{mL}$ heparin) at $45^{\circ} \mathrm{C}$ and 2 time for $5 \mathrm{~min}$ with $5 \mathrm{x}$ SSCT 
at RT. Cells were incubated with snap cooled hairpins $\mathrm{B} 1 \mathrm{H} 1$ and $\mathrm{B} 1 \mathrm{H} 2$ at room temperature for 12-16 hours. The concentrations of each hairpin (0.375 pmol, 1.875 pmol, and 3.75 pmol per well in an 8 well chamber slide) was proportional to the amount of initiator probe used $(0.8 \mathrm{nM}, 4 \mathrm{nM}$ or $8 \mathrm{nM})$. Cells were washed 5 times for 5 minutes at RT with 5x SSCT, then mounted with ProLong Gold antifade mountant with DAPI.

For human derived brain section, samples were processed according to Molecular Instrument's protocol. In brief, Histo-Clear II was used to deparaffinize tissue, then samples were rehydrated and treated with proteinase $\mathrm{K}$ as described for FISH. , Slides were washed in $1 \times$ TBST, incubated in $0.2 \mathrm{~N} \mathrm{HCL}$ for $20 \mathrm{~min}$ at RT, washed5 times in $5 \times S S C T$, then incubated in $0.1 \mathrm{M}$ triethanolamine-HCR $(\mathrm{pH} 8.0)$ with acetic anhydride for $10 \mathrm{~min}$, and washed in 5x SSCT for $5 \mathrm{~min}$. Slides were preheated and incubated in hybridization buffer with probes at $45^{\circ} \mathrm{C}$ in humidity chambers for $12-16 \mathrm{hrs}$. The remaining steps weree the same as above for HCR in cell culture.

8) Imaging and analysis

Images were taken on an Olympus FV1000 confocal microscope equipped with a 40x oil objective (60x for iPSC images). ImageJ software was used to analyzed the exported images. The backgrounds for stained proteins and repeat RNA signals were normalized to non-transfected group or controls unless indicated. Total cell number, protein stained cell number, RNA positive cell number, and foci number and distribution per cell were all manually counted. Signal intensities for iPSC images (Supplemental Figure 2E) were calculated as mean intensity/area using ImageJ. For transfected MEFs, RNA intensity was graded into high, medium and low signal intensity. The ratio of repeat positive cells was calculated as number of RNA positive cells to total cells. The ratio of foci number per cell was calculated as foci number in all repeat positive cells divided by all repeat positive cells. The repeat distribution was expressed as proportion of cells with foci (only nuclear, only cytoplasmic and both) among all repeat positive cells. The relationship between repeat foci and SGs was analyzed as the proportion of co-localization of cytoplasmic $\mathrm{G}_{4} \mathrm{C}_{2}$ repeat foci with G3BP1 granule to total cytoplasmic $\mathrm{G}_{4} \mathrm{C}_{2}$ repeat foci. Similarly, the relationship between repeat foci and NBs was analyzed as the proportion of co-localization of nuclear $\mathrm{G}_{4} \mathrm{C}_{2}$ repeat foci with 
TDP43 granule to all nuclear $\mathrm{G}_{4} \mathrm{C}_{2}$ repeat foci.

9) Statistical analysis

All statistical analyses were performed in GraphPad Prism software. Chi-square test was applied for categorical data, including amount of stained protein and repeat cells in transfected MEFs, repeat intensity in transfected MEFs, and distribution of repeat foci in cells. Unpaired t-test, one-way ANOVA and two-way ANOVA were performed to analyze continuous data, including number of detectable repeat foci, foci number per cell, and the co-association rates between repeat RNA and SG or NB markers. We designated $P<0.05$ as our threshold for significance.

Supplemental Table 1. Information for human derived samples.

\begin{tabular}{|c|c|c|c|c|}
\hline Sample ID & Lab ID & Type & Diagnosis & $\mathrm{CGG} / \mathrm{G}_{4} \mathrm{C}_{2}$ repeat $\mathrm{NO}$. \\
\hline C9-C1 & 499 & fibroblasts & C9-ALS/FTD & $\mathrm{G}_{4} \mathrm{C}_{2}=1180$ \\
\hline $\mathrm{C} 9-\mathrm{C} 2$ & 733 & fibroblasts & C9-ALS/FTD & $\mathrm{G}_{4} \mathrm{C}_{2}=1100$ \\
\hline C9-C3 & 953 & fibroblasts & C9-ALS/FTD & $\mathrm{G}_{4} \mathrm{C}_{2}=1230$ \\
\hline Control-C1 & C1 & fibroblasts & Control & $\mathrm{CGG}=31$ \\
\hline Control-C4 & $\mathrm{C} 4$ & fibroblasts & Control & $\mathrm{CGG}=22$ \\
\hline C9-B1 & $\exp 198$ & Brain-cb & C9-ALS/FTD & Expanded (RP-PCR) \\
\hline C9-B2 & $\exp 1233$ & Brain-cb & C9-ALS/FTD & Expanded (RP-PCR) \\
\hline \multirow[t]{2}{*}{ C9-B3 } & \multirow[t]{2}{*}{$\exp 1350$} & Brain-cb & \multirow[t]{2}{*}{ C9-ALS/FTD } & \multirow[t]{2}{*}{ Expanded (RP-PCR) } \\
\hline & & Brain-cortex & & \\
\hline \multirow[t]{2}{*}{ Control-B1 } & \multirow[t]{2}{*}{ cont1033 } & Brain-cb & \multirow[t]{2}{*}{ Control } & \multirow[t]{2}{*}{ n.d. } \\
\hline & & Brain-cortex & & \\
\hline Control-B2 & cont1533 & Brain-cb & Control & n.d. \\
\hline FXTAS-1 & $\mathrm{F} 1$ & fibroblast & FXTAS & $C G G=122$ \\
\hline FXTAS-3 & F3 & fibroblast & FXTAS & CGG $=97$ \\
\hline Premutation-3 & P3 & fibroblast & $\begin{array}{l}\text { Premutation } \\
\text { carrier }\end{array}$ & $C G G=81$ \\
\hline Premuation-4 & P4 & fibroblast & $\begin{array}{l}\text { Premutation } \\
\text { carrier }\end{array}$ & $\mathrm{CGG}=70$ \\
\hline FXTAS-B1 & 1906 & Brain-hippo & FXTAS & CGG=102 \\
\hline \multirow[t]{2}{*}{ FXTAS-B2 } & \multirow[t]{2}{*}{ T345 } & Brain-hippo & \multirow[t]{2}{*}{ FXTAS } & \multirow[t]{2}{*}{$\mathrm{CGG}=90$} \\
\hline & & Brain-cortex & & \\
\hline
\end{tabular}




\begin{tabular}{|l|l|l|l|l|}
\hline Control-B3 & 340 & $\begin{array}{l}\text { Brains- } \\
\text { cortex }\end{array}$ & Control & n.d. \\
\hline Control-B4 & T357 & $\begin{array}{l}\text { Brains- } \\
\text { cortex }\end{array}$ & Control & n.d. \\
\hline C9-neuron & 882 & Neuron & C9-ALS/FTD & $\mathrm{G}_{4} \mathrm{C}_{2}>44$ \\
\hline Control-neuron & 1021 & Neuron & Control & $\mathrm{G}_{4} \mathrm{C}_{2}=14$ \\
\hline WT & wt4-6 & iPSC & Control & CGG $=30$ \\
\hline TC43 & TC43 & iPSC & $\begin{array}{l}\text { unmethylated } \\
\text { FM }\end{array}$ & CG $=270$ \\
\hline FXS & $139-2$ & iPSC & FXS & CGG $=$ 800 \\
\hline
\end{tabular}

Supplemental table 2. LNA FISH probe and HCR probe sequences

\begin{tabular}{|l|l|}
\hline Category & Product sequence 5'-3' \\
\hline $\mathrm{G}_{4} \mathrm{C}_{2}$ repeat FISH LNA probe & $\begin{array}{l}\text { /5TYE665/CCC+CGGC+CCC+GGC+CCCG+GCC } \\
+ \text { CCG+GCC+CCG+GCC+CCGG }\end{array}$ \\
\hline CGG repeat FISH LNA probe & $\begin{array}{l}\text { /5TYE665/CCG+CCGC+CGCCG+CCG+CCG+CC } \\
\text { GCCG }\end{array}$ \\
\hline $\mathrm{G}_{4} \mathrm{C}_{2}$ repeat initiator probe & $\begin{array}{l}\text { GAGGAGGGCAGCAAACGGGAAGAGTCTTCCTTTACGATATTCCCCG } \\
\text { GCCCCGGCCCCGGCCCCGGCCCCGGCCCGGATATAGCATTCTTTCT } \\
\text { TGAGGAGGGCAGCAAACGGGAAGAG }\end{array}$ \\
\hline CGG repeat initiator probe & $\begin{array}{l}\text { GAGGAGGGCAGCAAACGGGAAGAGTCTTCCTTTACGATATTCCGCC } \\
\text { GCCGCCGCCGCCGCCGCCGATATAGCATTCTTTCTTGAGGAGGGCA } \\
\text { GCAAACGGGAAGAG }\end{array}$ \\
\hline
\end{tabular}

+ represent the location for LNA

Supplemental table 3. Reporter Sequences

\begin{tabular}{|l|l|}
\hline Reporter & Sequence \\
\hline$\left.{ }_{3} \mathrm{G}_{2} \mathrm{C}_{4}\right)_{47}$-NL- & TAATACGACTCACTATAGGGAGACCCAAGCTGGCTAGCGTGTGTGTTTTTGTTTTTC \\
& CCACCCTCTCTCCCCACTACTTGCTCTCACAGTACTCGCTGAGGGTGAACAAGAAA \\
& AGACCTGATAAAGATTAACCAGAAGAAACAAGGAGGGAAACAACCGCAGCCTGTA \\
& GCAAGCTCTGGAACTCAGGatgAGTCGCGCGCTATCTAGACCGGCCCCGGCCCG \\
& GCCCCGGCCCCGGCCCCGGCCCCGGCCCCGGCCCCGGCCCCGGCCCCGGCCC \\
& CGGCCCCGGCCCCGGCCCCGGCCCCGGCCCCGGCCCCGGCCCCGGCCCGGC \\
& CCCGGCCCCGGCCCCGGCCCCGGCCCCGGCCCCGGCCCCGGCCCCGGCCCG \\
& GCCCCGGCCCCGGCCCCGGCCCCGGCCCCTGCCCCGGCCCCGGCCCCGGCCC \\
& CGGCCCCGGCCCCGGCCCCGGCCCCGGCCCCGGCCCCGGCCCCGGCCCCGGC \\
& CCCGGCCCCTCTAGAAGCTTGGCAATCCGGTACTGTTGGTAAAGCCACCGGGGTC \\
& TTCACACTCGAAGATTTCGTTGGGGACTGGCGACAGACAGCCGGCTACAACCTGG \\
\hline
\end{tabular}




\begin{tabular}{|c|c|}
\hline & $\begin{array}{l}\text { ACCAAGTCCTTGAACAGGGAGGTGTGTCCAGTTTGTTTCAGAATCTCGGGGTGTCC } \\
\text { GTAACTCCGATCCAAAGGATTGTCCTGAGCGGTGAAAATGGGCTGAAGATCGACAT } \\
\text { CCATGTCATCATCCCGTATGAAGGTCTGAGCGGCGACCAAATGGGCCAGATCGAAA } \\
\text { AAATTTTTAAGGTGGTGTACCCTGTGGATGATCATCACTTTAAGGTGATCCTGCACTA } \\
\text { TGGCACACTGGTAATCGACGGGGTTACGCCGAACATGATCGACTATTTCGGACGGC } \\
\text { CGTATGAAGGCATCGCCGTGTTCGACGGCAAAAAGATCACTGTAACAGGGACCCTG } \\
\text { TGGAACGGCAACAAAATTATCGACGAGCGCCTGATCAACCCCGACGGCTCCCTGCT } \\
\text { GTTCCGAGTAACCATCAACGGAGTGACCGGCTGGCGGCTGTGCGAACGCATTCTGG } \\
\text { CGGACTACAAAGACCATGACGGTGATTATAAAGATCATGACATCGATTACAAGGATGA } \\
\text { CGATGACAAGTAAGGCCGCGACTCGAGAGGGCCC }\end{array}$ \\
\hline $\begin{array}{l}\text { FMRpolyG }_{100^{-}} \\
3 x F\end{array}$ & $\begin{array}{l}\text { GGATCCACTAGTCCAGTGTGGTGGAATTCGTTAACAGATCTGCTCAGCTCCGTTTCG } \\
\text { GTTTCACTTCCGGTGGAGGGCCGCCTCTGAGCGGGCGGCGGGCCGACGGCGAGC } \\
\text { GCGGGCGGCGGCGGTGACGGAGGCGCCGCTGCCAGGGGGCGTGCGGCAGCGCG } \\
\text { GCGGCGGCGGCGGCGGCGGCGGAGGCGGCGGCGGCGGCGGCGGCGGCGGCGG } \\
\text { CGGCGGCGGCGGCGGCGGCGGCGGCGGCGGCGGCGGCGGCGGCGGCGGCGGC } \\
\text { GGCGGCGGCGGCGGCGGCGGCGGCGGCGGCGGCGGCGGCGGCGGCGGCGGCG } \\
\text { GCGGCGGCGGCGGCGGCGGCGGCGGCGGCGGCGGCGGCGGCGGCGGCGGCGG } \\
\text { CGGCGGCGGCGGCGGCGGCGGCGGCGGCGGCGGCGGCGGCGGCGGCGGCGGC } \\
\text { GGCGGCGGCGGCGGCGGCGGCGGCGGCGGCGGCGGCGGCGGCTGGGCCTCGA } \\
\text { GCGCCCGCAGCCCACCTCTCGGGGGCGGGCTCCCGGCGCTAGCAGGGCTGAAGA } \\
\text { GAAGATGGAGGAGCTGGTGGTGGAAGGCGGGGCTCCAATGGCGCTTTCTACAAGG } \\
\text { CATTTGAAAGCGGCCGCAGACTACAAAGACCATGACGGTGATTATAAAGATCATGACA } \\
\text { TCGACTACAAGGATGACGATGACAAGTAAGGGCCC }\end{array}$ \\
\hline
\end{tabular}

\section{Acknowledgements:}

The authors thank Geena Skariah for providing UFM, FXS, and WT iSPC cells for analysis, Amy Krans for assistance with C9orf72 ALS/FTD and FXTAS brain tissues, and Michael Sutton for the use of his confocal microscope Special thanks to David Turner, and Harry Choi for their inspiration and guidance in designing HCR probes. Brain samples were obtained from the University of Michigan Brain Bank with help from Steven Goutman and Eva Feldman in the ALS Center at the University of Michigan who also assisted with provision of fibroblasts.

\section{Funding:}

This work was funded by grants from the NIH (P50HD104463, R01NS099280 and 
R01NS086810 to PKT and T32NS00722237 to MRG) and the VA (BLRD BX004842 to PKT). MRG was supported by the A2A3 Susan Ross Award. YZ was supported by the Chinese Scholarship Council and by private philanthropic support to PKT. 


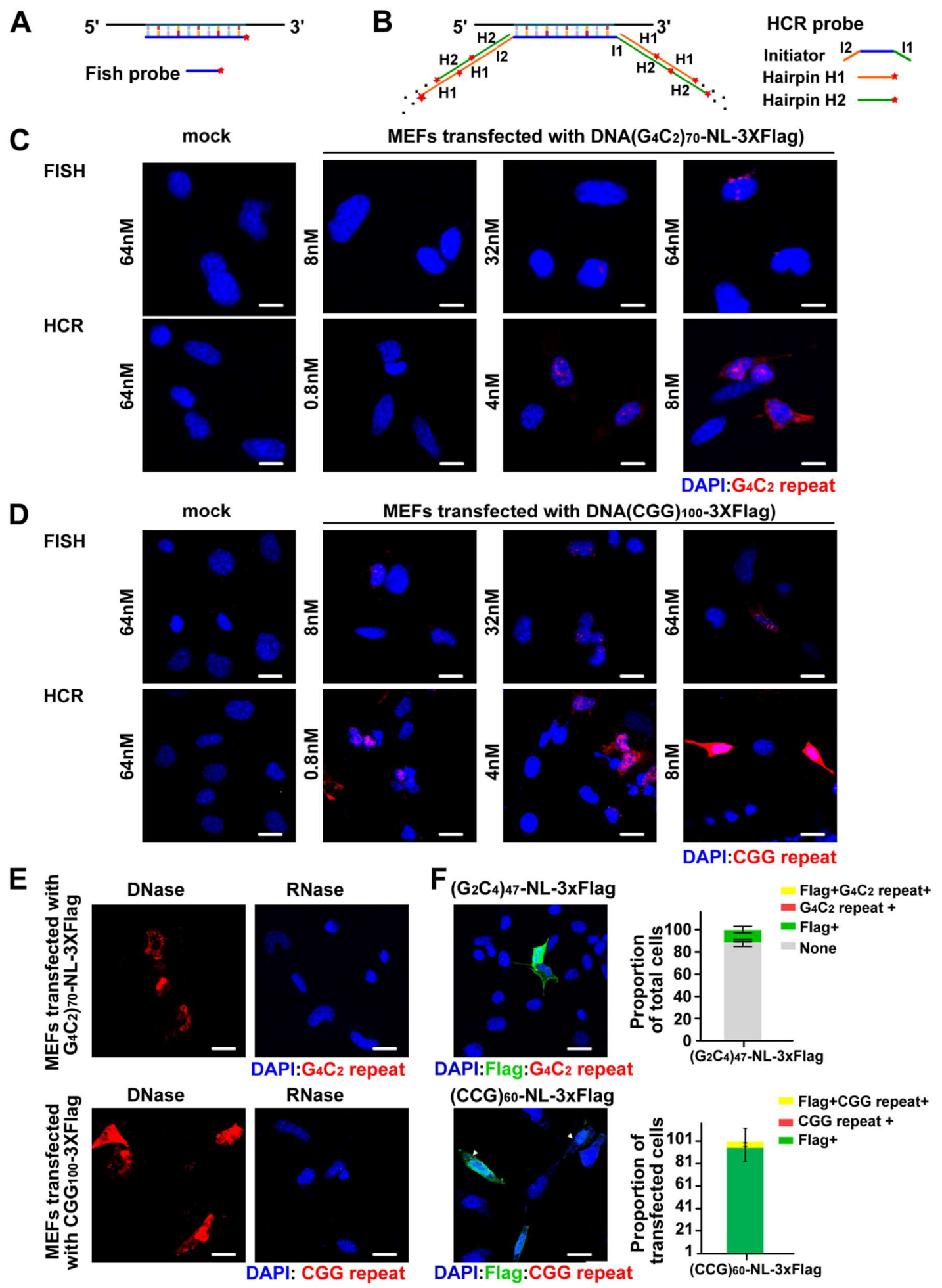

Figure 1

Figure 1. Hybridization Chain Reaction mediated detection of GC rich repeats.

A) FISH probe with a 5' conjugated fluorophore. Signal strength is dependent on number of RNA molecules 
present. B) In HCR, three probes are used: the initiator binds directly to the RNA of interest and has both 3' and 5' extensions complementary to two 5' fluorophore conjugated hairpin probes (H1 and H2). Upon binding, $\mathrm{H} 1$ and $\mathrm{H} 2$ unfold to reveal new binding sites for the other hairpin probe. In this way, signal from one RNA molecule is amplified $>100$ fold, dramatically enhancing detection. C-D) MEFs transfected with $\left(\mathrm{G}_{4} \mathrm{C}_{2}\right)_{70}$-NL-3xFlag (C) or $\mathrm{CGG}_{100}$-3xFlag (D) vectors and probed with indicated concentrations of either FISH or HCR probe. E) MEFs transfected with $\left(\mathrm{G}_{4} \mathrm{C}_{2}\right)_{70}$-NL-3xFlag expressing vector (top) or $\mathrm{CGG}_{100^{-}}$ 3xFlag vector (bottom) and treated with DNase (left) or RNase (right) prior to HCR. F) MEFs transfected with antisense $\left(\mathrm{G}_{2} \mathrm{C}_{4}\right)_{47}$ (top) or (CCG) 60 (bottom) expressing plasmids followed by ICC stained with Flag and HCR sense strand probes $\left(\mathrm{C}_{4} \mathrm{G}_{2}\right)_{6}$ or $(\mathrm{CCG})_{8}$. Top: $\mathrm{N}=434$; Bottom: $\mathrm{N}=38$. Error bars indicate $95 \%$ confidence intervals (CI). Scale bar $=20 \mu \mathrm{m}$ in $\mathrm{C}, \mathrm{D}, \mathrm{E} ; 50 \mu \mathrm{m}$ in F. 
A

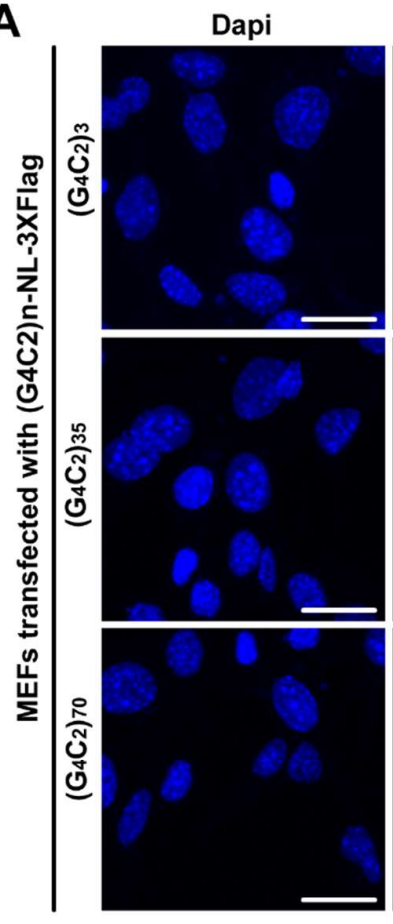

D

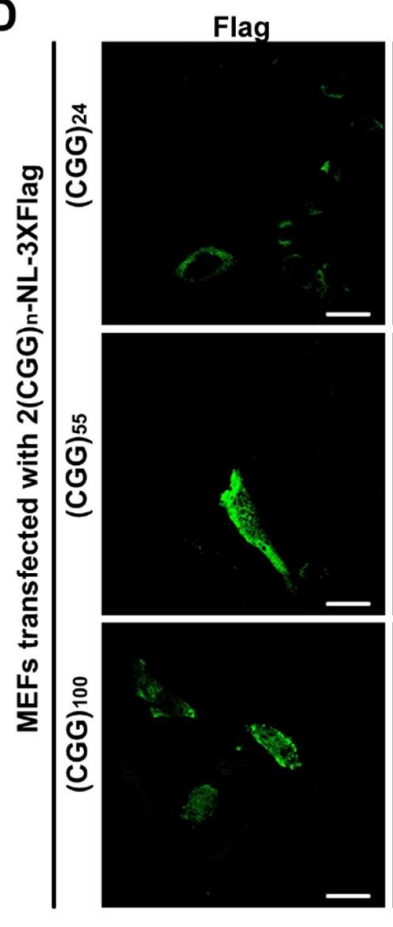

$\mathrm{G}_{4} \mathrm{C}_{2}$ RNA

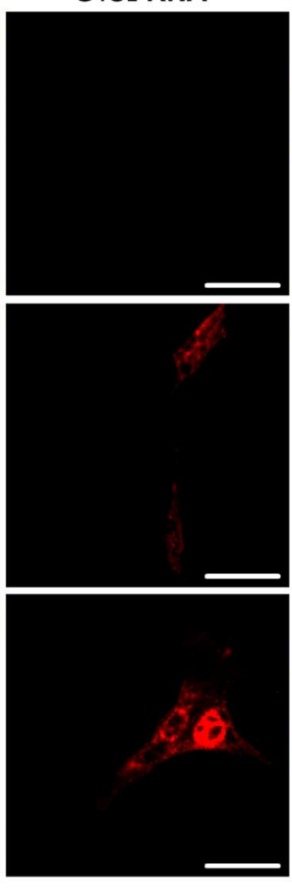

CGG RNA
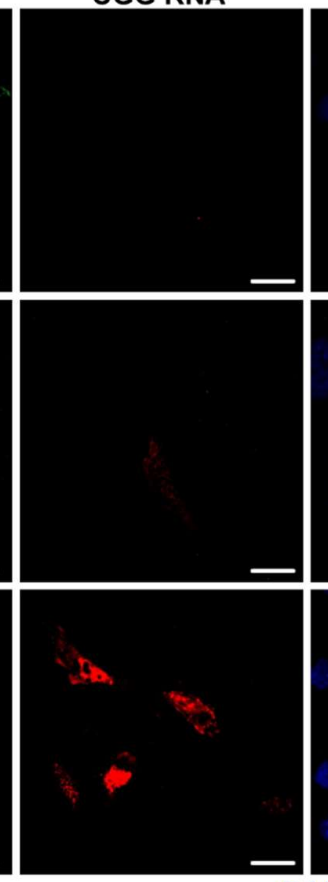

Composite
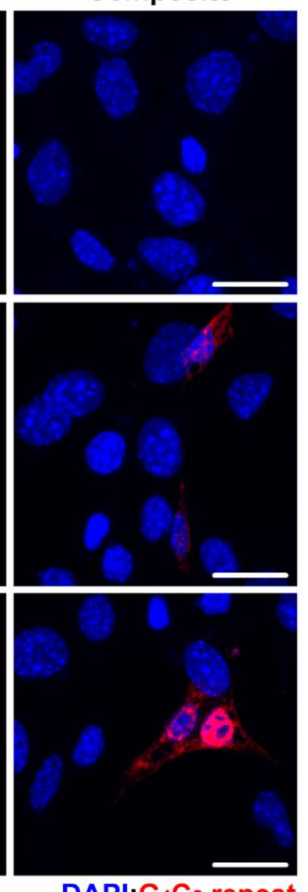

DAPI: $\mathrm{G}_{4} \mathrm{C}_{2}$ repeat
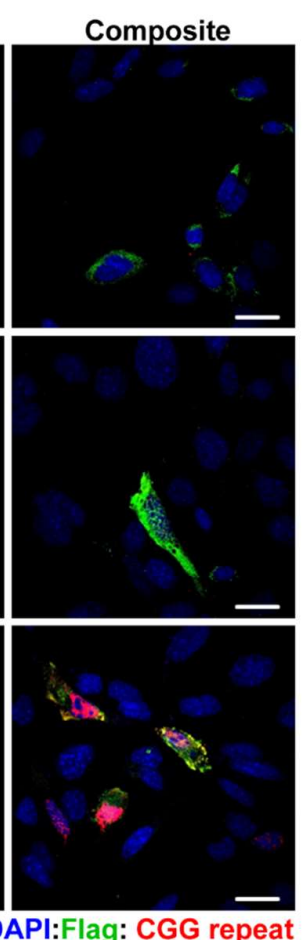

B
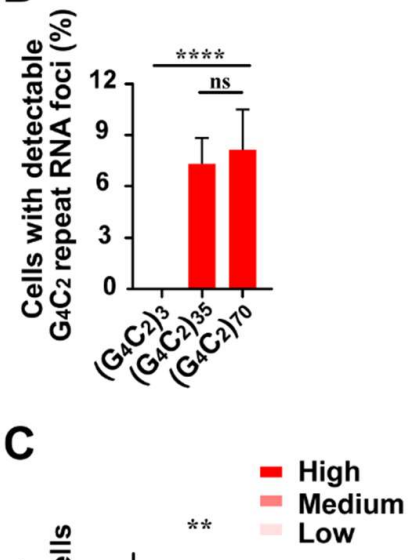

$\mathbf{E}$

- CGG repeat polyA+CGG repeat - polyA

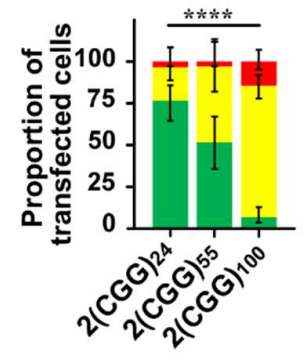

$\mathbf{F}$

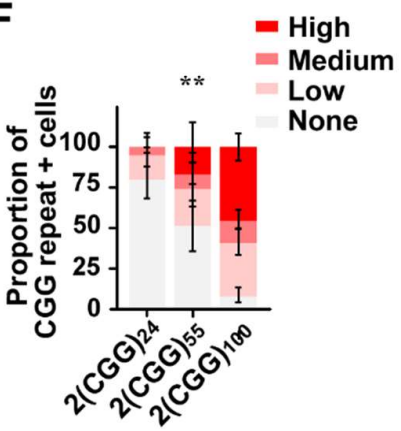

Figure 2

Figure 2. HCR probe signal intensity is repeat length dependent for $\mathrm{G}_{\mathbf{4}} \mathrm{C}_{\mathbf{2}}$ and CGG repeats.

A) MEFs transfected with $\mathrm{G}_{4} \mathrm{C}_{2}$ repeat constructs with increasing repeat sizes. B) Quantification of cells with detectable $\mathrm{G}_{4} \mathrm{C}_{2}$ repeat RNA foci in total cells. $\left(\mathrm{G}_{4} \mathrm{C}_{2}\right)_{3}$ : $\mathrm{N}=313 ;\left(\mathrm{G}_{4} \mathrm{C}_{2}\right)_{35} \mathrm{~N}=575 ;\left(\mathrm{G}_{4} \mathrm{C}_{2}\right)_{70} \mathrm{~N}=514$. C) 
HCR signal intensity in MEFs transfected with $\left(\mathrm{G}_{4} \mathrm{C}_{2}\right)_{\mathrm{n}}-\mathrm{NL}-3 \mathrm{xF}$ reporters with indicated repeat length. $\left(\mathrm{G}_{4} \mathrm{C}_{2}\right)_{35}: \mathrm{N}=175 ;\left(\mathrm{G}_{4} \mathrm{C}_{2}\right)_{70}$ : $\mathrm{N}=110$. D) MEFs transfected with CGG repeat constructs with increasing repeat sizes. E) Quantification of Flag+ and CGG RNA+ cells expressed as proportion of total transfected cells. F) HCR signal intensity in MEFs transfected with 2(CGG)n-NL-3xF reporters with indicated repeat length. EF) $\mathrm{N} \geq 35 /$ condition. Error bar indicates $95 \% \mathrm{CI}$. Statistics: one-way ANOVA for B, Chi-square test for C, E and F. ${ }^{* *} p<0.01,{ }^{* * *} p<0.0001$, ns: not significant. Scale bar $=50 \mu \mathrm{m}$ in A and D. 
A
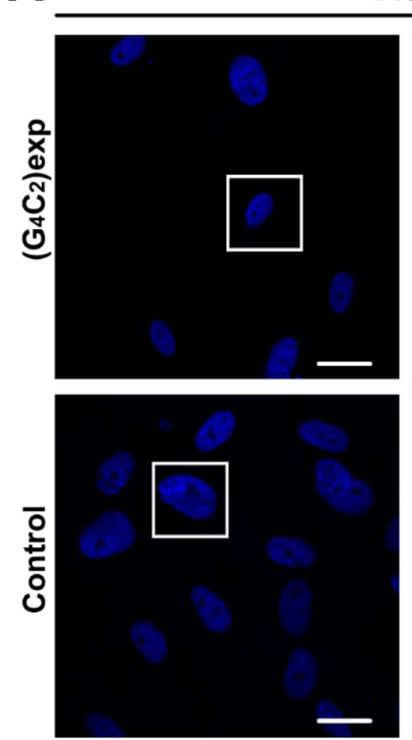

C

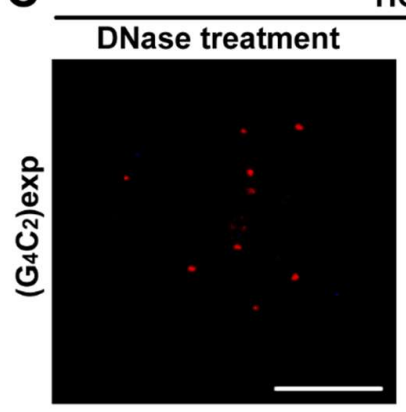

HCR

\section{RNase treatment}

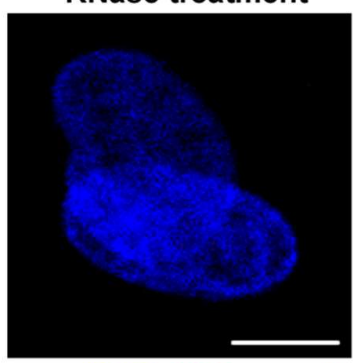

DAPI: $\mathrm{G}_{4} \mathrm{C}_{2}$ repeat

E

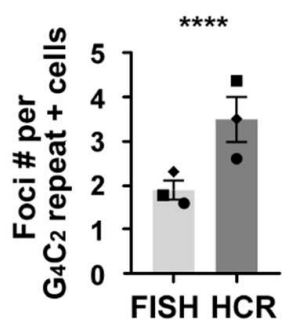

B
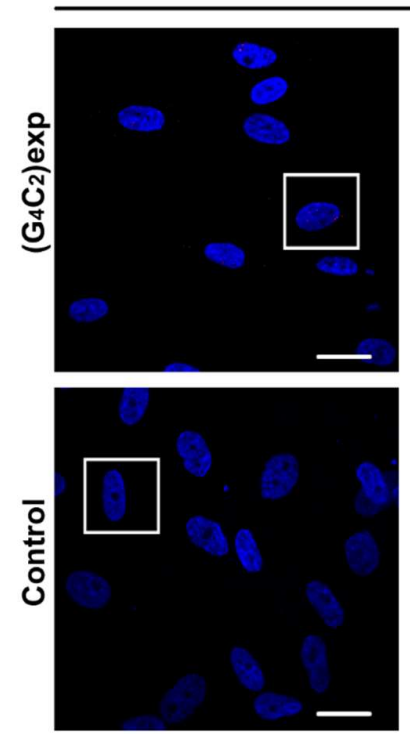

D

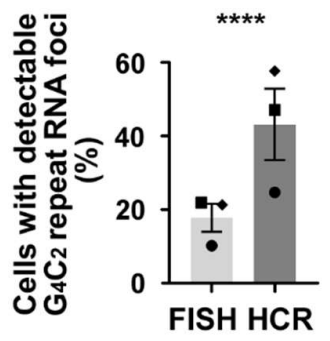

F

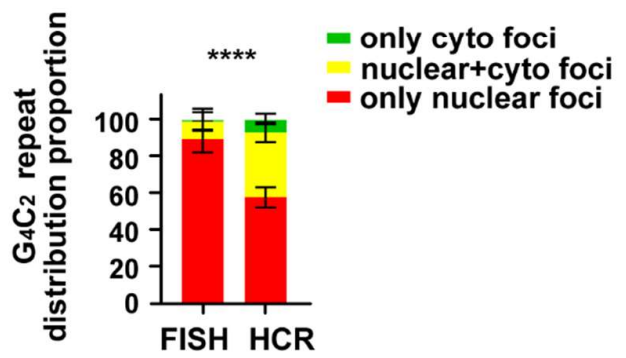

Figure 3. HCR is more sensitive than FISH in detecting endogenous $\mathrm{G}_{4} \mathrm{C}_{2}$ repeat signal from $\mathrm{C} 9 O \mathrm{OF} 72$ ALS-FTD patient fibroblasts.

A-C) C9ORF72 ALS-FTD patients and control fibroblasts by FISH and HCR, and treated with DNase and RNase prior to HCR. Higher magnification images of the boxed areas are shown on the right. D) Quantification of cells with detectable $\mathrm{G}_{4} \mathrm{C}_{2}$ repeat RNA foci in total cells for fibroblasts. FISH: $\mathrm{N}=577$; HCR: $N=690$. E-F) Quantification of RNA foci number per RNA+ cell and the distribution for RNA foci. The dot shapes represent individual cell lines, which were each assayed in triplicate. FISH: N=106 and HCR: $\mathrm{N}=305$ for E-F). Error bars in D, E indicate SEM, and in F shows 95\% CI. Statistics: two-way ANOVA for $\mathrm{D}$ and $\mathrm{E}$, Chi-square test for $\mathrm{F}$. ${ }^{* * * *} p<0.0001$. Scale bar $=50 \mu \mathrm{m}$ in left for $\mathrm{A}$ and $\mathrm{B} ; 20 \mu \mathrm{m}$ in right for $\mathrm{A}$ 
and $\mathrm{B}$, and $\mathrm{C}$.

A
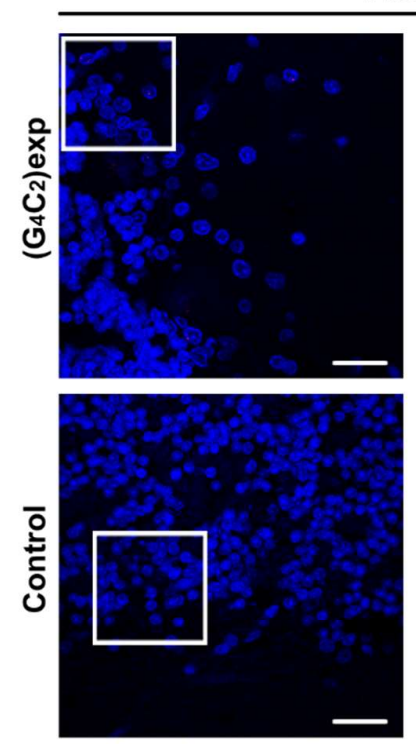

C

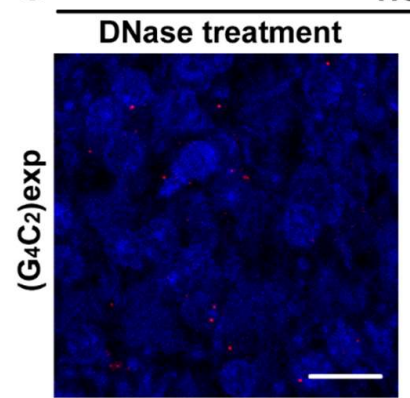

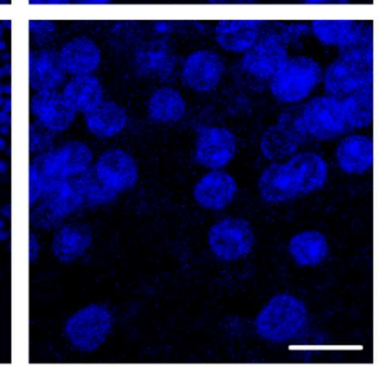

DAPI: $\mathrm{G}_{4} \mathrm{C}_{2}$ repeat

FISH

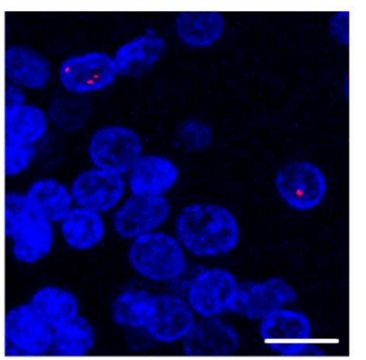

HCR

\section{RNase treatment}

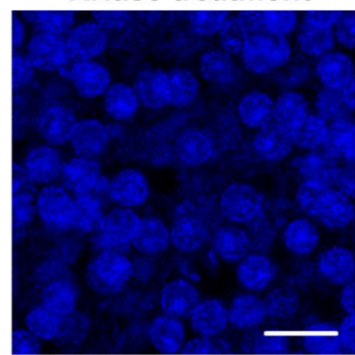

$\mathrm{DAPI}: \mathrm{G}_{4} \mathrm{C}_{2}$ repeat
B
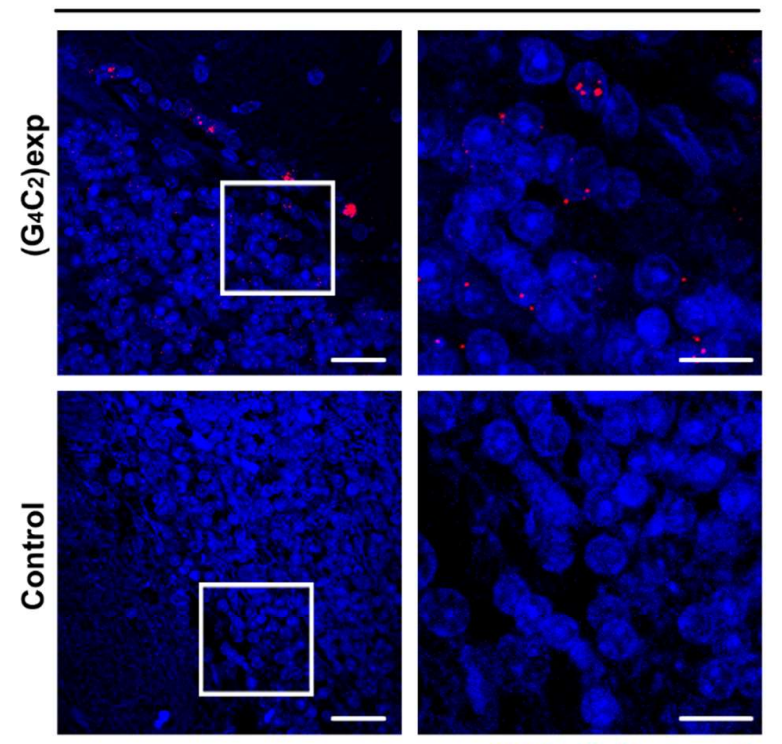

DAPI: $\mathrm{G}_{4} \mathrm{C}_{2}$ repeat

D

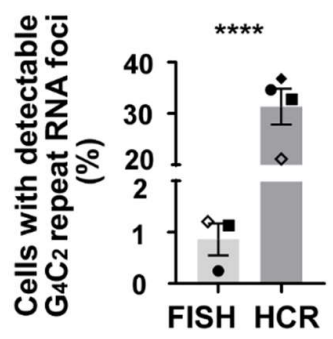

Figure 4. $\mathrm{HCR}$ is more sensitive than $\mathrm{FISH}$ in detecting endogenous $\mathrm{G}_{4} \mathrm{C}_{2}$ repeat signal from $\mathrm{C} 9 \mathrm{ORF} 72$ ALS-FTD patient brains.

A-C) FISH (A) and HCR (B) of C9ORF72 ALS-FTD patient and control cerebellum, and (C) treated with DNase and RNase prior to HCR. Higher magnification images of the boxed areas are shown on the right. D) Quantification of cells with detectable $\mathrm{G}_{4} \mathrm{C}_{2}$ repeat RNA foci in total cells for brains \pm SEM. The dot shapes indicate different brain samples. The black dots are from cerebellum and unfilled dots are from frontal cortex. FISH: N=2976; HCR: N=3285. Statistics: two-way ANOVA for D. $* * * * p<0.0001$. Scale bar=50 $\mu$ $\mathrm{m}$ in left for $\mathrm{A}$ and $\mathrm{B} ; 20 \mu \mathrm{m}$ in right for $\mathrm{A}$ and $\mathrm{B}$, and $\mathrm{C}$. 
A

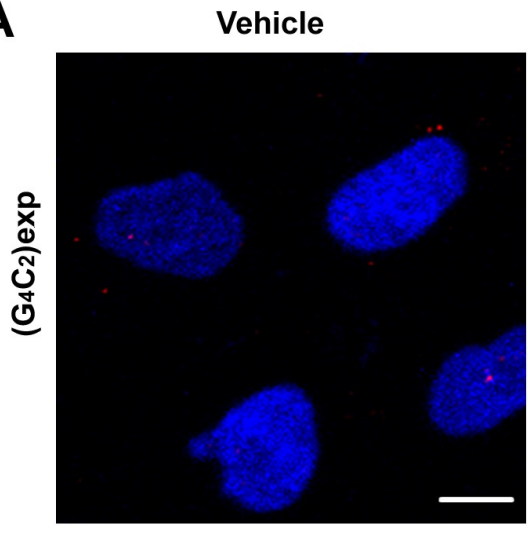

B

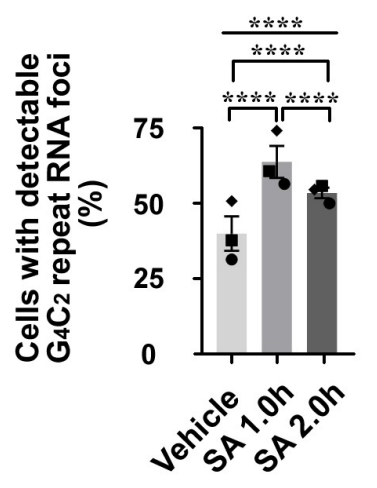

SA 1.0h

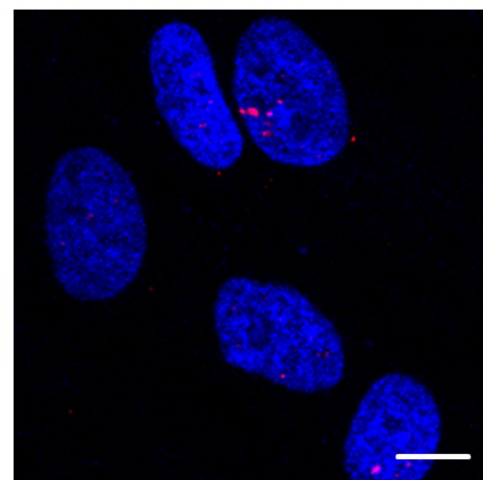

C

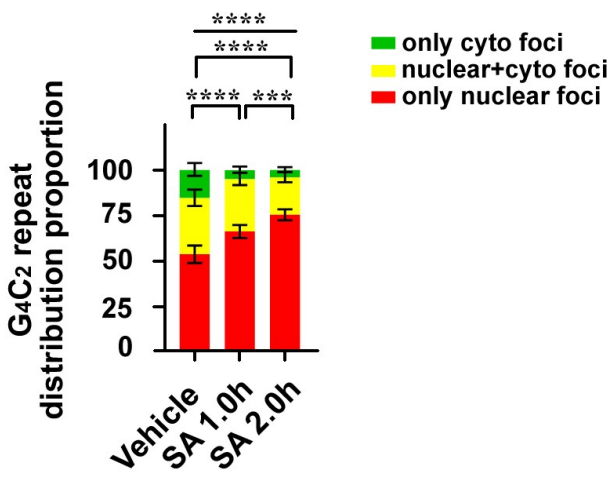

SA 2.0h

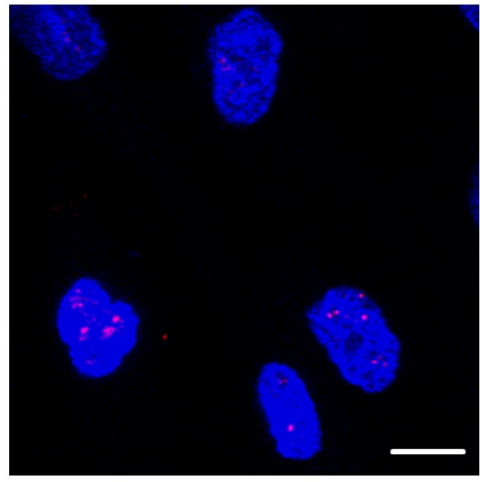

DAPI: ${ }_{4} C_{2}$ repeat

Figure 5. $\mathrm{G}_{4} \mathrm{C}_{2}$ repeats redistribute into the nucleus during stress in $C 9 O R F 72$ ALS-FTD patient fibroblasts.

A) C9ORF72 ALS-FTD patient fibroblasts treated with $\mathrm{H}_{2} \mathrm{O}$ (vehicle) or sodium arsenite (SA) for the indicated times prior to fixation and HCR. B) Quantification of cells with detectable $\mathrm{G}_{4} \mathrm{C}_{2}$ repeat RNA foci in total cells $\pm \mathrm{SEM}$. The dot shapes represent different $\mathrm{G}_{4} \mathrm{C}_{2}$ repeat expansion cell lines. $\mathrm{N}=1130$ for vehicle, 1120 for SA 1.0h, and 1482 for SA 2.0h. C) Distribution of $\mathrm{G}_{4} \mathrm{C}_{2}$ repeat RNA foci with or without SA treatment $\pm 95 \%$ CI. N=400 for vehicle, 679 for SA 1.0h, and 775 for SA 2.0h. Statistics: two-way ANOVA for B, Chi-square test for C. ***p<0.001, ****p<0.0001. Scale bar $=10 \mu \mathrm{m}$ in A. 
A
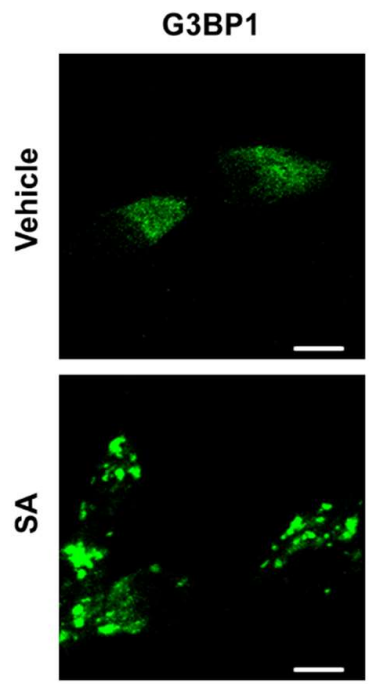

B

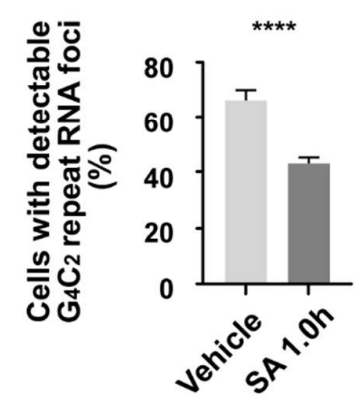

G4C2 RNA
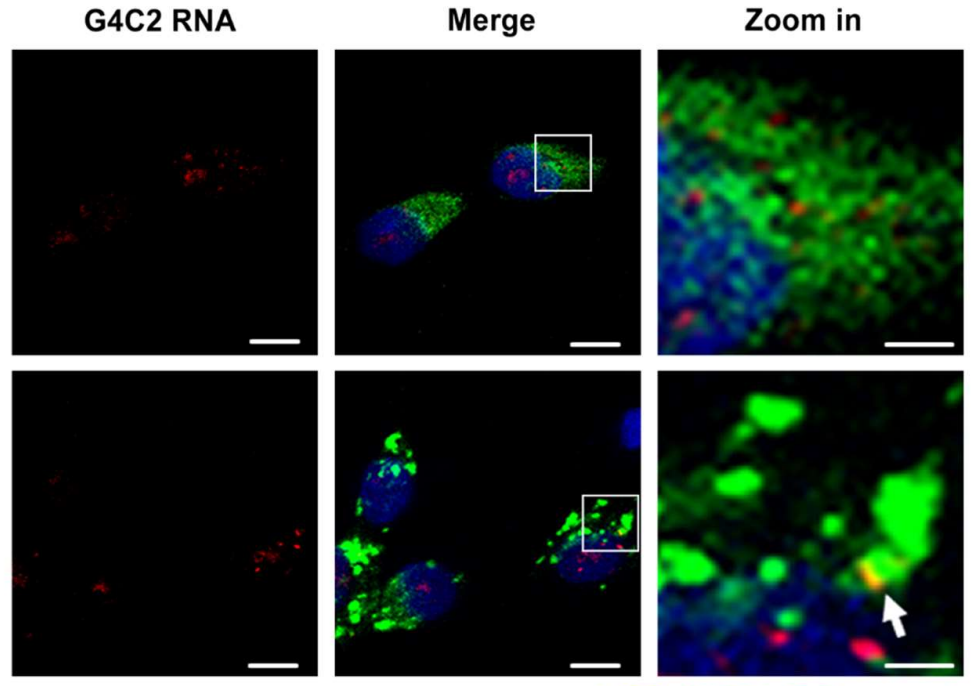

DAPI:G3BP1: $\mathrm{G}_{4} \mathrm{C}_{2}$ repeat

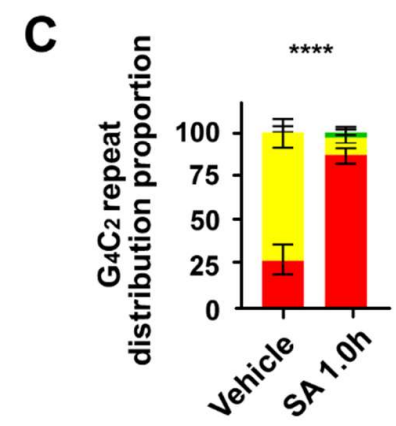

- only cyto foci

nuclear+cyto foci

- only nuclear foci

Figure 6. $\mathrm{G}_{4} \mathrm{C}_{2}$ repeats redistribute in the nucleus during stress in C9ORF72 ALS-FTD patient neurons. A) $C 9$ orf 72 patient derived neurons treated with $\mathrm{H}_{2} \mathrm{O}$ or SA prior to HCR-ICC. G3BP1= stress granule marker. A higher magnification of the boxed areas are shown on the right. White arrows indicate rare colocalization events between cytoplasmic G4C2 repeats and G3BP1. B) Cell with detectable $\mathrm{G}_{4} \mathrm{C}_{2}$ repeat RNA among total neurons treated with or without SA \pm SEM. N=156 for vehicle and 535 for SA $1.0 \mathrm{~h}$. C) Quantification of the distribution of repeat RNA in all repeat positive neurons $\pm 95 \%$ CI. N=104 for vehicle and 233 for SA 1.0h. Statistics: unpaired t test for B and Chi-square test for C. $* * * * p<0.0001$. Scale bar $=10 \mu \mathrm{m}$ in A except for the zoom in images $(2.5 \mu \mathrm{m})$. 
A
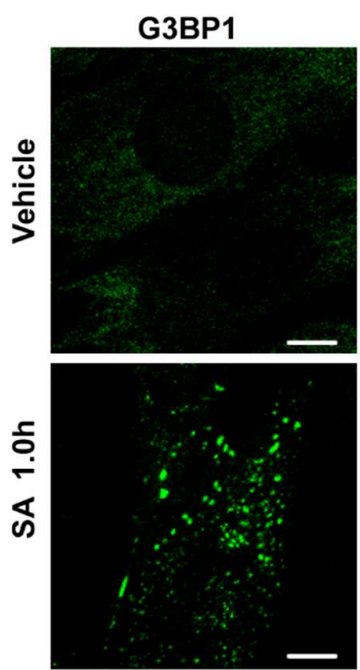

B

\begin{tabular}{lccc}
\hline & Total cell \# counted & Cytoplasmic foci \# counted & Cytoplasmic foci + G3BP1 (ns) \\
\hline Vehicle & 374 & 150 & $0.67 \% \pm 0.67 \%$ \\
SA 1.0h & 253 & 87 & $3.45 \% \pm 1.97 \%$ \\
\hline
\end{tabular}

C
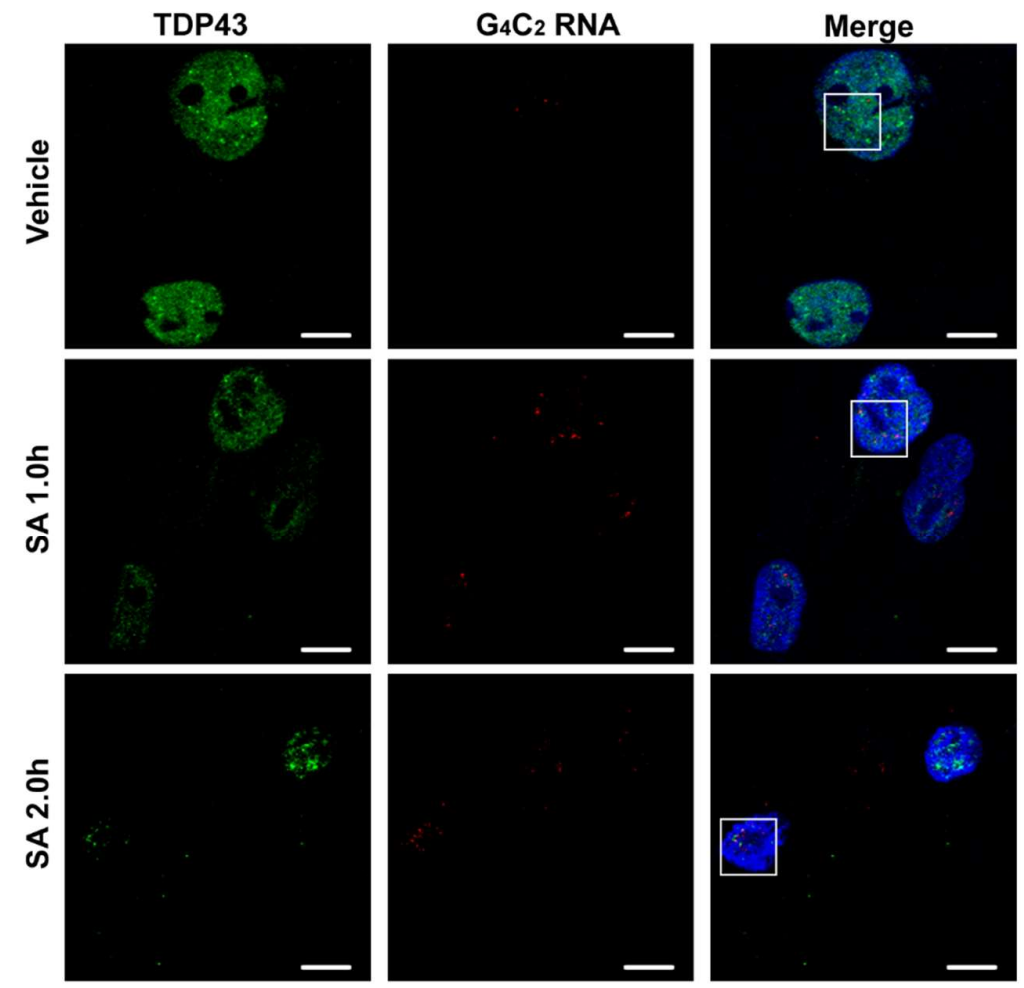

DAPI:TDP43: $\mathrm{G}_{4} \mathrm{C}_{2}$ repeat

D

\begin{tabular}{cccccccccc}
\hline & \multicolumn{3}{c}{ Total cell \# counted } & \multicolumn{3}{c}{ Nuclear foci \# counted } & \multicolumn{3}{c}{ Nuclear foci + TDP43 } \\
\cline { 2 - 10 } & C9-C1 & C9-C2 & C9-C3 & C9-C1 & C9-C2 & C9-C3 & C9-C1(**) & C9-C2(ns) & C9-C3(**) \\
\hline Vehicle & 187 & 426 & 143 & 265 & 245 & 107 & $0.38 \% \pm 0.38 \%$ & $4.49 \% \pm 1.33 \%$ & $1.87 \% \pm 1.31 \%$ \\
SA 1.0h & 205 & 466 & 196 & 914 & 479 & 390 & $3.72 \% \pm 0.63 \%$ & $8.35 \% \pm 1.27 \%$ & $2.56 \% \pm 0.80 \%$ \\
SA 2.0h & 379 & 520 & 278 & 856 & 1097 & 545 & $5.72 \% \pm 0.79 \%$ & $8.02 \% \pm 0.82 \%$ & $6.97 \% \pm 1.09 \%$ \\
\hline
\end{tabular}

Figure 7 
Figure 7. $\mathrm{G}_{4} \mathrm{C}_{2}$ repeats rarely co-localize with cytoplasmic G3BP1 or nuclear TDP43 during stress.

A) $C 9$ orf 72 patient derived fibroblasts treated 1 hour with $\mathrm{H}_{2} \mathrm{O}$ or SA prior to HCR-ICC. G3BP1= stress granule marker. Higher magnification images of the boxed areas are shown on the right. White arrows indicate co-localization of $\mathrm{G}_{4} \mathrm{C}_{2}$ repeat and G3BP1. B) Quantification of cytoplasmic $\mathrm{G}_{4} \mathrm{C}_{2}$ repeat foci colocalization with $\mathrm{G} 3 \mathrm{BP} 1$ as a fraction of all cytoplasmic $\mathrm{G}_{4} \mathrm{C}_{2}$ repeats. C) C9orf72 patient derived fibroblasts treated with $\mathrm{H}_{2} \mathrm{O}$ or SA (1 hour, 2 hours) prior to HCR-ICC. TDP43= nuclear body marker. White arrows indicate co-localization of $\mathrm{G} 4 \mathrm{C} 2$ repeat and TDP43. D) Quantification of nuclear $\mathrm{G}_{4} \mathrm{C}_{2}$ repeat foci colocalization with TDP43 as a fraction of all observed nuclear $\mathrm{G}_{4} \mathrm{C}_{2}$ repeat foci. \% shown as mean \pm SEM. Statistics: unpaired $\mathrm{t}$ test for B and one-way ANOVA for D. ${ }^{* *} p<0.01,{ }^{* * *} p<0.001$. ns: not significant. Scale bar $=10 \mu \mathrm{m}$ in A and $\mathrm{C}$ except for zoomed images $(2.5 \mu \mathrm{m})$. 
A

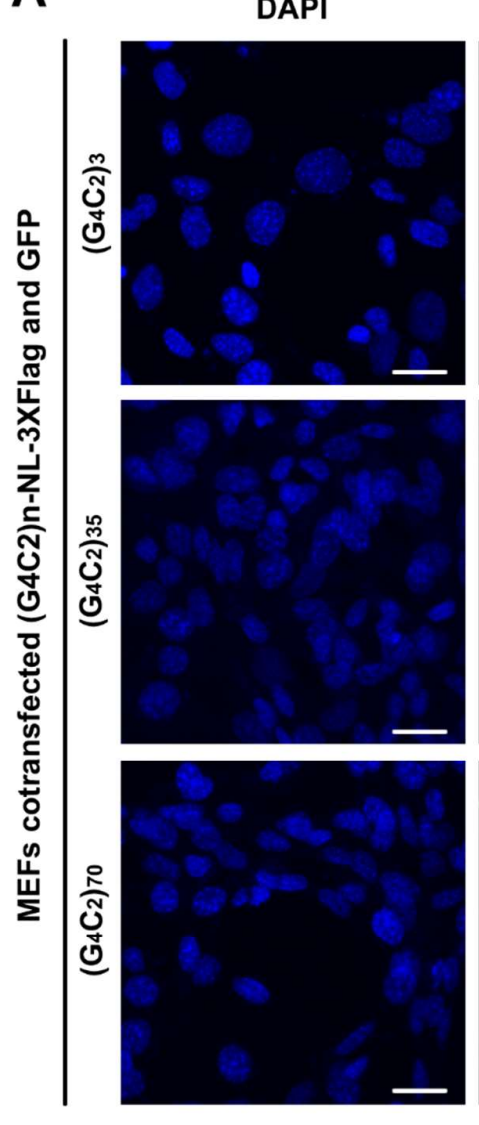

B

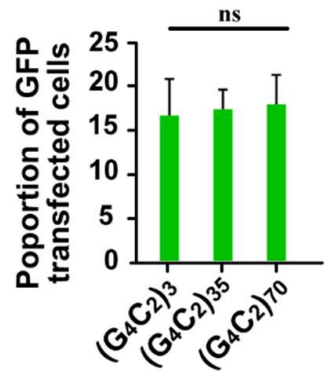

GFP
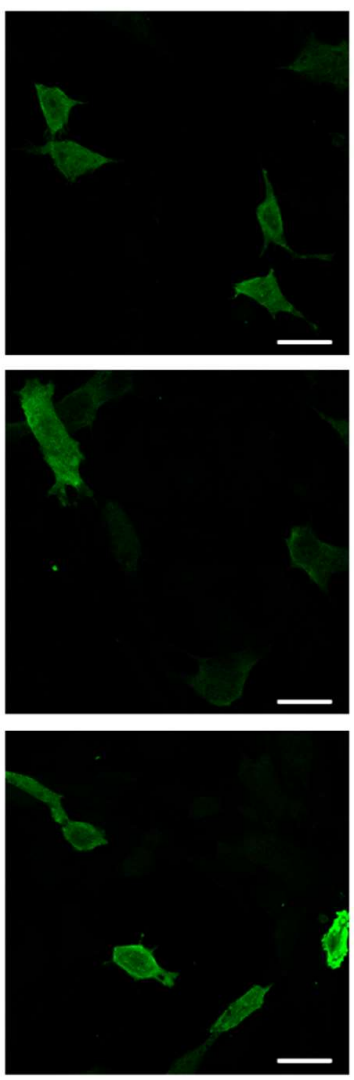

C
G4C2 RNA
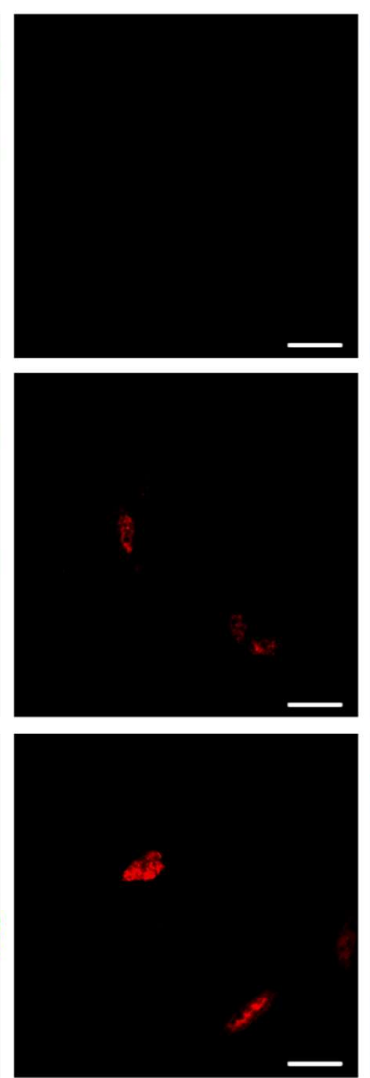

DAPI:GFP: $\mathrm{G}_{4} \mathrm{C}_{2}$ repeat
Merge
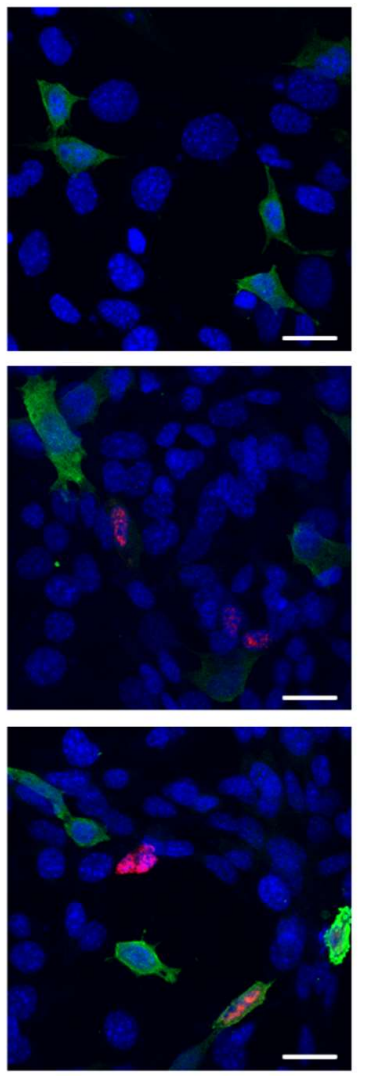

$-\mathrm{G}_{4} \mathrm{C}_{2}$ repeat

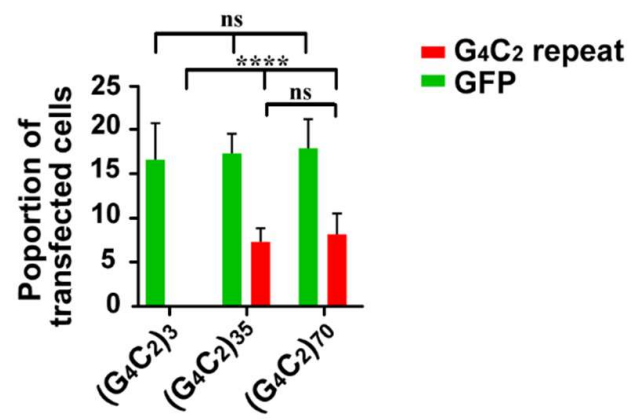

Supplemental Figure 1. Transfection efficiencies for MEFs co-transfected with $G F P$ and $\mathrm{G}_{4} \mathrm{C}_{2}$ repeats A) MEFs co-transfected with GFP and $\mathrm{G}_{4} \mathrm{C}_{2}$ repeat constructs with increasing repeat sizes. B-C) Quantification of cells with detectable GFP and $\mathrm{G}_{4} \mathrm{C}_{2}$ repeat RNA foci signal in total cells. $\left(\mathrm{G}_{4} \mathrm{C}_{2}\right)_{3}: \mathrm{N}=313$; $\left(\mathrm{G}_{4} \mathrm{C}_{2}\right)_{35} \mathrm{~N}=575 ;\left(\mathrm{G}_{4} \mathrm{C}_{2}\right)_{70} \mathrm{~N}=514$. Statistics: one-way ANOVA for $\mathrm{B}$, one-way ANOVA and unpaired t test for C. $* * * * p<0.0001$, ns: not significant. Scale bar=50 $\mu \mathrm{m}$ in A. 


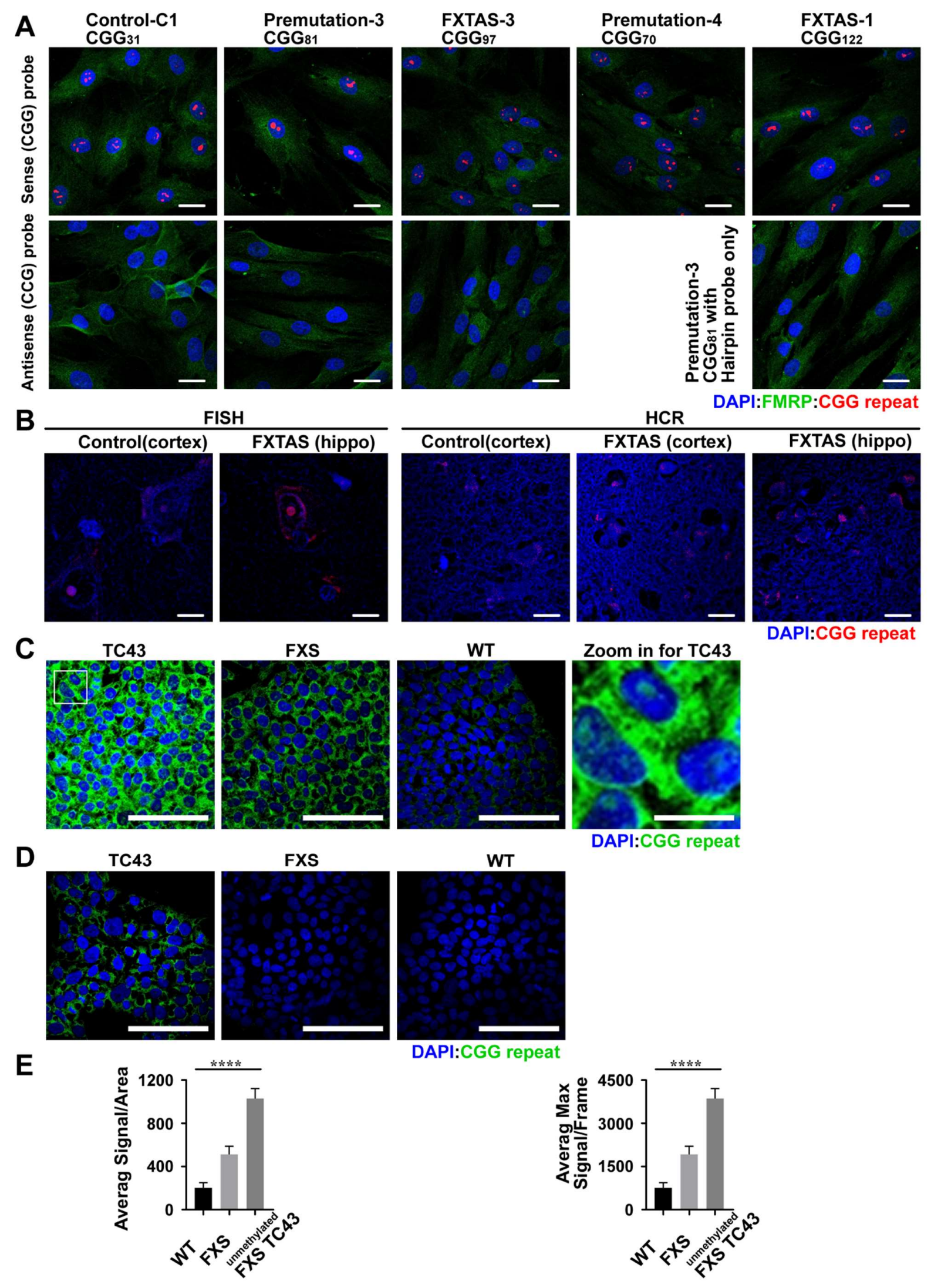

Supplemental Figure 2. 


\section{Supplemental Figure 2 legend: Endogenous CGG repeat is highly expressed in human cells.}

A) HCR of FXTAS patient, permutation carrier and control fibroblasts. B) FISH and HCR of FXTAS patient and control brains. C-D) iPSCs/hESCs derived from an unmethylated CGG expansion carrier (TC-43; 270 CGG repeats, transcriptionally active), fully methylated embryonic cells (FXS, 800 CGG repeats, transcriptionally silent) and a control patient (30 CGG repeats) were assayed by CGG HCR. Panel C is without background subtraction, demonstrating signal in all cells. Panel D is after subtraction of signal detected in FXS line, revealing significant signal above background only in the actively transcribed expanded CGG repeat line. E) Quantification of CGG repeat RNA foci signal in each cell line of figure (C) left: average signal/frame, right: maximum signal/frame. Statistics of one-way ANOVA for E. $\mathrm{n}=15, * * * * p<0.0001$. Scale bar $=50 \mu \mathrm{m}$ in $\mathrm{A} ; 20 \mu \mathrm{m}$ in $\mathrm{B} ; 100 \mu \mathrm{m}$ in $\mathrm{C}$ and $\mathrm{D}$ except for the zoom in picture of $\mathrm{C}(20 \mu \mathrm{m})$. 


\section{References:}

Bajc Cesnik, A., S. Darovic, S. Prpar Mihevc, M. Stalekar, M. Malnar, H. Motaln, Y. B. Lee, J. Mazej, J. Pohleven, M. Grosch, M. Modic, M. Fonovic, B. Turk, M. Drukker, C. E. Shaw, and B. Rogelj. 2019. 'Nuclear RNA foci from C90RF72 expansion mutation form paraspeckle-1ike bodies', J Cell Sci, 132.

Belzil, V. V., P. 0. Bauer, M. Prudencio, T. F. Gendron, C. T. Stetler, I. K. Yan, L. Pregent, L. Daughrity, M. C. Baker, R. Rademakers, K. Boylan, T. C. Patel, D. W. Dickson, and L. Petrucelli. 2013. 'Reduced C9orf72 gene expression in c9FTD/ALS is caused by histone trimethylation, an epigenetic event detectable in blood', Acta Neuropathol, 126: 895-905.

Burgess, H. M., W. A. Richardson, R. C. Anderson, C. Salaun, S. V. Graham, and N. K. Gray. 2011. 'Nuclear relocalisation of cytoplasmic poly(A)-binding proteins PABP1 and PABP4 in response to UV irradiation reveals mRNA-dependent export of metazoan PABPs', J Cel1 Sci, 124: 3344-55.

Chen, L. S., F. Tassone, P. Sahota, and P. J. Hagerman. 2003. ' The (CGG)n repeat element within the 5' untranslated region of the FMR1 message provides both positive and negative cis effects on in vivo translation of a downstream reporter', Hum Mol Genet, 12: $3067-74$.

Cheng, W., S. Wang, A. A. Mestre, C. Fu, A. Makarem, F. Xian, L. R. Hayes, R. Lopez-Gonzalez, K. Drenner, J. Jiang, D. W. Cleveland, and S. Sun. 2018. ' C90RF72 GGGGCC repeatassociated non-AUG translation is upregulated by stress through eIF2alpha phosphorylation', Nat Commun, 9: 51.

Choi, H. M., V. A. Beck, and N. A. Pierce. 2014a. 'Multiplexed in situ hybridization using hybridization chain reaction', Zebrafish, 11: 488-9.

- - - 2014b. 'Next-generation in situ hybridization chain reaction: higher gain, lower cost, greater durability', ACS Nano, 8: 4284-94.

Choi, H. M. T., M. Schwarzkopf, M. E. Fornace, A. Acharya, G. Artavanis, J. Stegmaier, A. Cunha, and N. A. Pierce. 2018. 'Third-generation in situ hybridization chain reaction: multiplexed, quantitative, sensitive, versatile, robust', Development, 145.

Choi, J., K. R. Love, Y. Gong, T. M. Gierahn, and J. C. Love. 2011. 'Immuno-hybridization chain reaction for enhancing detection of individual cytokine-secreting human peripheral mononuclear cells', Anal Chem, 83: 6890-5.

Chou, C. C., Y. Zhang, M. E. Umoh, S. W. Vaughan, I. Lorenzini, F. Liu, M. Sayegh, P. G. Donlin-Asp, Y. H. Chen, D. M. Duong, N. T. Seyfried, M. A. Powers, T. Kukar, C. M. Hales, M. Gearing, N. J. Cairns, K. B. Boylan, D. W. Dickson, R. Rademakers, Y. J. Zhang, L. Petrucelli, R. Sattler, D. C. Zarnescu, J. D. Glass, and W. Rossol1. 2018. ' TDP-43 pathology disrupts nuclear pore complexes and nucleocytoplasmic transport in ALS/FTD', Nat Neurosci, 21: 228-39.

Conlon, E. G., L. Lu, A. Sharma, T. Yamazaki, T. Tang, N. A. Shneider, and J. L. Manley. 2016. 'The C90RF72 GGGGCC expansion forms RNA G-quadruplex inclusions and sequesters hnRNP $H$ to disrupt splicing in ALS brains', Elife, 5.

Cooper-Knock, J., M. J. Walsh, A. Higginbottom, J. Robin Highley, M. J. Dickman, D. Edbauer, P. G. Ince, S. B. Wharton, S. A. Wilson, J. Kirby, G. M. Hautbergue, and P. J. Shaw. 2014. 'Sequestration of multiple RNA recognition motif-containing proteins by C9orf72 
repeat expansions', Brain, 137: 2040-51.

DeJesus-Hernandez, M., N. A. Finch, X. Wang, T. F. Gendron, K. F. Bieniek, M. G. Heckman, A. Vasilevich, M. E. Murray, L. Rousseau, R. Weesner, A. Lucido, M. Parsons, J. Chew, K. A. Josephs, J. E. Parisi, D. S. Knopman, R. C. Petersen, B. F. Boeve, N. R. GraffRadford, J. de Boer, Y. W. Asmann, L. Petrucelli, K. B. Boylan, D. W. Dickson, M. van Blitterswijk, and R. Rademakers. 2017. 'In-depth clinico-pathological examination of RNA foci in a large cohort of C90RF72 expansion carriers', Acta Neuropathol, 134: 255-69.

DeJesus-Hernandez, M., I. R. Mackenzie, B. F. Boeve, A. L. Boxer, M. Baker, N. J. Rutherford, A. M. Nicholson, N. A. Finch, H. Flynn, J. Adamson, N. Kouri, A. Wojtas, P. Sengdy, G. Y. Hsiung, A. Karydas, W. W. Seeley, K. A. Josephs, G. Coppola, D. H. Geschwind, Z. K. Wszolek, H. Feldman, D. S. Knopman, R. C. Petersen, B. L. Miller, D. W. Dickson, K. B. Boylan, N. R. Graff-Radford, and R. Rademakers. 2011. 'Expanded GGGGCC hexanucleotide repeat in noncoding region of C90RF72 causes chromosome 9p-1inked FTD and ALS', Neuron, 72: 245-56.

Didiot, M. C., C. M. Ferguson, S. Ly, A. H. Coles, A. 0. Smith, A. A. Bickne11, L. M. Ha11, E. Sapp, D. Echeverria, A. A. Pai, M. DiFiglia, M. J. Moore, L. J. Hayward, N. Aronin, and A. Khvorova. 2018. 'Nuclear Localization of Huntingtin mRNA Is Specific to Cells of Neuronal Origin', Cell Rep, 24: 2553-60 e5.

Duan, Y., A. Du, J. Gu, G. Duan, C. Wang, X. Gui, Z. Ma, B. Qian, X. Deng, K. Zhang, L. Sun, K. Tian, Y. Zhang, H. Jiang, C. Liu, and Y. Fang. 2019. 'PARylation regulates stress granule dynamics, phase separation, and neurotoxicity of disease-related RNA-binding proteins', Cell Res, 29: 233-47.

Echeverria, G. V., and T. A. Cooper. 2012. 'RNA-binding proteins in microsatellite expansion disorders: mediators of RNA toxicity', Brain Res, 1462: 100-11.

Fardaei, M., M. T. Rogers, H. M. Thorpe, K. Larkin, M. G. Hamshere, P. S. Harper, and J. D. Brook. 2002. 'Three proteins, MBNL, MBLL and MBXL, co-localize in vivo with nuclear foci of expanded-repeat transcripts in DM1 and DM2 cells', Hum Mol Genet, 11: 80514.

Fay, M. M. , P. J. Anderson, and P. Ivanov. 2017. 'ALS/FTD-Associated C90RF72 Repeat RNA Promotes Phase Transitions In Vitro and in Cells', Cell Rep, 21: 3573-84.

Ferguson, M. L., and D. R. Larson. 2013. 'Measuring transcription dynamics in living cells using fluctuation analysis', Methods Mol Biol, 1042: 47-60.

Frottin, F., F. Schueder, S. Tiwary, R. Gupta, R. Korner, T. Schlichthaerle, J. Cox, R. Jungmann, F. U. Hart1, and M. S. Hipp. 2019. 'The nucleolus functions as a phaseseparated protein quality control compartment', Science, 365: 342-47.

Gasset-Rosa, F., S. Lu, H. Yu, C. Chen, Z. Melamed, L. Guo, J. Shorter, S. Da Cruz, and D. W. Cleveland. 2019. 'Cytoplasmic TDP-43 De-mixing Independent of Stress Granules Drives Inhibition of Nuclear Import, Loss of Nuclear TDP-43, and Ce11 Death', Neuron, 102: 339-57 e7.

Green, K. M., M. R. Glineburg, M. G. Kearse, B. N. Flores, A. E. Linsalata, S. J. Fedak, A. C. Goldstrohm, S. J. Barmada, and P. K. Todd. 2017. 'RAN translation at C9orf72associated repeat expansions is selectively enhanced by the integrated stress response', Nat Commun, 8: 2005. 
Groh, M., M. M. Lufino, R. Wade-Martins, and N. Gromak. 2014. 'R-1oops associated with triplet repeat expansions promote gene silencing in Friedreich ataxia and fragile X syndrome', PLoS Genet, 10: e1004318.

Haenfler, J. M. , G. Skariah, C. M. Rodriguez, A. Monteiro da Rocha, J. M. Parent, G. D. Smith, and P. K. Todd. 2018. 'Targeted Reactivation of FMR1 Transcription in Fragile X Syndrome Embryonic Stem Cel1s', Front Mol Neurosci, 11: 282.

Haeusler, A. R., C. J. Donnelly, G. Periz, E. A. Simko, P. G. Shaw, M. S. Kim, N. J. Maragakis, J. C. Troncoso, A. Pandey, R. Sattler, J. D. Rothstein, and J. Wang. 2014. 'C9orf72 nucleotide repeat structures initiate molecular cascades of disease', Nature, 507: 195-200.

Hagerman, R. J., M. Leehey, W. Heinrichs, F. Tassone, R. Wilson, J. Hills, J. Grigsby, B. Gage, and P. J. Hagerman. 2001. 'Intention tremor, parkinsonism, and generalized brain atrophy in male carriers of fragile X', Neurology, 57: 127-30.

Hoem, G., C. R. Raske, D. Garcia-Arocena, F. Tassone, E. Sanchez, A. L. Ludwig, C. K. Iwahashi, M. Kumar, J. E. Yang, and P. J. Hagerman. 2011. ' CGG-repeat length threshold for FMR1 RNA pathogenesis in a cellular model for FXTAS', Hum Mol Genet, 20: 216170 .

Iwahashi, C. K., D. H. Yasui, H. J. An, C. M. Greco, F. Tassone, K. Nannen, B. Babineau, C. B. Lebrilla, R. J. Hagerman, and P. J. Hagerman. 2006. 'Protein composition of the intranuclear inclusions of FXTAS', Brain, 129: 256-71.

Jain, A., and R. D. Vale. 2017. 'RNA phase transitions in repeat expansion disorders', Nature, 546: 243-47.

Jin, P., R. Duan, A. Qurashi, Y. Qin, D. Tian, T. C. Rosser, H. Liu, Y. Feng, and S. T. Warren. 2007. 'Pur alpha binds to rCGG repeats and modulates repeat-mediated neurodegeneration in a Drosophila model of fragile X tremor/ataxia syndrome', Neuron, 55: $556-64$.

Johnson, S. J., and T. A. Cooper. 2021. 'Overlapping mechanisms of 1ncRNA and expanded microsatellite RNA', Wiley Interdiscip Rev RNA, 12: e1634.

Kearse, M. G., K. M. Green, A. Krans, C. M. Rodriguez, A. E. Linsalata, A. C. Goldstrohm, and P. K. Todd. 2016. 'CGG Repeat-Associated Non-AUG Translation Utilizes a CapDependent Scanning Mechanism of Initiation to Produce Toxic Proteins', Mol Cell, 62: $314-22$.

Kedersha, N., G. Stoecklin, M. Ayodele, P. Yacono, J. Lykke-Andersen, M. J. Fritzler, D. Scheuner, R. J. Kaufman, D. E. Golan, and P. Anderson. 2005. 'Stress granules and processing bodies are dynamically linked sites of mRNP remodeling', J Cell Biol, 169: $871-84$.

Khateb, S., P. Weisman-Shomer, I. Hershco-Shani, A. L. Ludwig, and M. Fry. 2007. 'The tetraplex (CGG)n destabilizing proteins hnRNP $\mathrm{A} 2$ and $\mathrm{CBF}-\mathrm{A}$ enhance the in vivo translation of fragile X premutation mRNA', Nucleic Acids Res, 35: 5775-88.

Kozlowski, P., M. de Mezer, and W. J. Krzyzosiak. 2010. 'Trinucleotide repeats in human genome and exome', Nucleic Acids Res, 38: 4027-39.

Krans, A., G. Skariah, Y. Zhang, B. Bayly, and P. K. Todd. 2019. 'Neuropathology of RAN translation proteins in fragile X-associated tremor/ataxia syndrome', Acta Neuropathol Commun, 7: 152. 
La Spada, A. R., E. M. Wilson, D. B. Lubahn, A. E. Harding, and K. H. Fischbeck. 1991. 'Androgen receptor gene mutations in X-1inked spinal and bulbar muscular atrophy', Nature, 352: 77-9.

Lee, Y. B., H. J. Chen, J. N. Peres, J. Gomez-Deza, J. Attig, M. Stalekar, C. Troakes, A. L. Nishimura, E. L. Scotter, C. Vance, Y. Adachi, V. Sardone, J. W. Miller, B. N. Smith, J. M. Gallo, J. Ule, F. Hirth, B. Rogelj, C. Houart, and C. E. Shaw. 2013. 'Hexanucleotide repeats in ALS/FTD form length-dependent RNA foci, sequester RNA binding proteins, and are neurotoxic', Cell Rep, 5: 1178-86.

Li, Y. R., 0. D. King, J. Shorter, and A. D. Gitler. 2013. 'Stress granules as crucibles of ALS pathogenesis', J Cell Biol, 201: 361-72.

Liu, J., J. Hu, A. T. Ludlow, J. T. Pham, J. W. Shay, J. D. Rothstein, and D. R. Corey. 2017. 'c9orf72 Disease-Related Foci Are Each Composed of One Mutant Expanded Repeat RNA', Cell Chem Biol, 24: 141-48.

Mahboubi, H., E. Seganathy, D. Kong, and U. Stochaj. 2013. 'Identification of Novel Stress Granule Components That Are Involved in Nuclear Transport', PLoS One, 8: e68356.

Mankodi, A., E. Logigian, L. Callahan, C. McClain, R. White, D. Henderson, M. Krym, and C. A. Thornton. 2000. 'Myotonic dystrophy in transgenic mice expressing an expanded CUG repeat', Science, 289: 1769-73.

Mankodi, A., C. R. Urbinati, Q. P. Yuan, R. T. Moxley, V. Sansone, M. Krym, D. Henderson, M. Schalling, M. S. Swanson, and C. A. Thornton. 2001. 'Muscleblind localizes to nuclear foci of aberrant RNA in myotonic dystrophy types 1 and 2', Hum Mol Genet, 10: $2165-70$.

Mehta, A. R., B. T. Selvaraj, S. K. Barton, K. McDade, S. Abrahams, S. Chandran, C. Smith, and J. M. Gregory. 2020. 'Improved detection of RNA foci in C9orf72 amyotrophic lateral sclerosis post-mortem tissue using BaseScope shows a lack of association with cognitive dysfunction', Brain Commun, 2: fcaa009.

Metz, A., J. Soret, C. Vourc'h, J. Tazi, and C. Jolly. 2004. 'A key role for stress-induced satellite III transcripts in the relocalization of splicing factors into nuclear stress granules', J Cel1 Sci, 117: 4551-8.

Miller, J. W., C. R. Urbinati, P. Teng-Umnuay, M. G. Stenberg, B. J. Byrne, C. A. Thornton, and M. S. Swanson. 2000. 'Recruitment of human muscleblind proteins to (CUG) (n) expansions associated with myotonic dystrophy', EMBO $J$, 19: 4439-48.

Mizielinska, S., T. Lashley, F. E. Norona, E. L. Clayton, C. E. Ridler, P. Fratta, and A. M. Isaacs. 2013. 'C9orf72 frontotemporal lobar degeneration is characterised by frequent neuronal sense and antisense RNA foci', Acta Neuropathol, 126: 845-57.

Nussbacher, J. K., R. Tabet, G. W. Yeo, and C. Lagier-Tourenne. 2019. 'Disruption of RNA Metabolism in Neurological Diseases and Emerging Therapeutic Interventions', Neuron, 102: 294-320.

Orr, H. T., and H. Y. Zoghbi. 2007. 'Trinucleotide repeat disorders', Annu Rev Neurosci, 30: $575-621$.

Patterson, J. R., M. P. Wood, and J. A. Schisa. 2011. 'Assembly of RNP granules in stressed and aging oocytes requires nucleoporins and is coordinated with nuclear membrane blebbing', Dev Biol, 353: 173-85.

Paulson, H. L., M. K. Perez, Y. Trottier, J. Q. Trojanowski, S. H. Subramony, S. S. Das, P. 
Vig, J. L. Mande1, K. H. Fischbeck, and R. N. Pittman. 1997. 'Intranuclear inclusions of expanded polyglutamine protein in spinocerebellar ataxia type 3', Neuron, 19: $333-44$.

Reddy, K., M. H. Schmidt, J. M. Geist, N. P. Thakkar, G. B. Panigrahi, Y. H. Wang, and C. E. Pearson. 2014. 'Processing of double-R-1oops in (CAG). (CTG) and C9orf72 (GGGGCC). (GGCCCC) repeats causes instability', Nucleic Acids Res, 42: 10473-87.

Reddy, K., M. Tam, R. P. Bowater, M. Barber, M. Tomlinson, K. Nichol Edamura, Y. H. Wang, and C. E. Pearson. 2011. 'Determinants of R-1oop formation at convergent bidirectionally transcribed trinucleotide repeats', Nucleic Acids Res, 39: 1749-62.

Renton, A. E., E. Majounie, A. Waite, J. Simon-Sanchez, S. Rollinson, J. R. Gibbs, J. C. Schymick, H. Laaksovirta, J. C. van Swieten, L. Myllykangas, H. Kalimo, A. Paetau, Y. Abramzon, A. M. Remes, A. Kaganovich, S. W. Scholz, J. Duckworth, J. Ding, D. W. Harmer, D. G. Hernandez, J. 0. Johnson, K. Mok, M. Ryten, D. Trabzuni, R. J. Guerreiro, R. W. Orre11, J. Neal, A. Murray, J. Pearson, I. E. Jansen, D. Sondervan, H. Seelaar, D. Blake, K. Young, N. Halliwe11, J. B. Callister, G. Toulson, A. Richardson, A. Gerhard, J. Snowden, D. Mann, D. Neary, M. A. Nalls, T. Peuralinna, L. Jansson, V. M. Isoviita, A. L. Kaivorinne, M. Holtta-Vuori, E. Ikonen, R. Sulkava, M. Benatar, J. Wuu, A. Chio, G. Restagno, G. Borghero, M. Sabate1li, Italsgen Consortium, D. Heckerman, E. Rogaeva, L. Zinman, J. D. Rothstein, M. Sendtner, C. Drepper, E. E. Eichler, C. Alkan, Z. Abdullaev, S. D. Pack, A. Dutra, E. Pak, J. Hardy, A. Singleton, N. M. Williams, P. Heutink, S. Pickering-Brown, H. R. Morris, P. J. Tienari, and B.

J. Traynor. 2011. 'A hexanucleotide repeat expansion in C90RF72 is the cause of chromosome 9p21-1inked ALS-FTD', Neuron, 72: 257-68.

Rodriguez, C. M., and P. K. Todd. 2019. 'New pathologic mechanisms in nucleotide repeat expansion disorders', Neurobiol Dis, 130: 104515.

Rodriguez, C. M., S. E. Wright, M. G. Kearse, J. M. Haenfler, B. N. Flores, Y. Liu, M. F. Ifrim, M. R. Glineburg, A. Krans, P. Jafar-Nejad, M. A. Sutton, G. J. Basse11, J. M. Parent, F. Rigo, S. J. Barmada, and P. K. Todd. 2020. 'A native function for RAN translation and CGG repeats in regulating fragile X protein synthesis', Nat Neurosci, 23: $386-97$.

Rossi, S., A. Serrano, V. Gerbino, A. Giorgi, L. Di Francesco, M. Nencini, F. Bozzo, M. E. Schinina, C. Bagni, G. Cestra, M. T. Carri, T. Achse1, and M. Cozzolino. 2015. 'Nuclear accumulation of mRNAs underlies G4C2-repeat-induced translational repression in a cellular model of C9orf72 ALS', J Cell Sci, 128: 1787-99.

Saxonov, S., P. Berg, and D. L. Brutlag. 2006. 'A genome-wide analysis of CpG dinucleotides in the human genome distinguishes two distinct classes of promoters', Proc Nat1 Acad Sci U S A, 103: 1412-7.

Sellier, C., F. Freyermuth, R. Tabet, T. Tran, F. He, F. Ruffenach, V. Alunni, H. Moine, C. Thibault, A. Page, F. Tassone, R. Willemsen, M. D. Disney, P. J. Hagerman, P. K. Todd, and N. Charlet-Berguerand. 2013. 'Sequestration of DROSHA and DGCR8 by expanded CGG RNA repeats alters microRNA processing in fragile X-associated tremor/ataxia syndrome', Cel1 Rep, 3: 869-80.

Sellier, C., F. Rau, Y. Liu, F. Tassone, R. K. Hukema, R. Gattoni, A. Schneider, S. Richard, R. Willemsen, D. J. Elliott, P. J. Hagerman, and N. Charlet-Berguerand. 2010. 'Sam68 
sequestration and partial loss of function are associated with splicing alterations in FXTAS patients', EMBO J, 29: 1248-61.

Sofola, O. A., P. Jin, Y. Qin, R. Duan, H. Liu, M. de Haro, D. L. Nelson, and J. Botas. 2007. 'RNA-binding proteins hnRNP A2/B1 and CUGBP1 suppress fragile X CGG premutation repeat-induced neurodegeneration in a Drosophila model of FXTAS', Neuron, 55: 56571.

Sonobe, Y., G. Ghadge, K. Masaki, A. Sendoe1, E. Fuchs, and R. P. Roos. 2018. 'Translation of dipeptide repeat proteins from the C90RF72 expanded repeat is associated with cellular stress', Neurobiol Dis, 116: 155-65.

Spille, J. H., M. Hecht, V. Grube, W. K. Cho, C. Lee, and Cisse, II. 2019. 'A CRISPR/Cas9 platform for MS2-labelling of single mRNA in live stem cells', Methods, 153: 35-45.

Sulovari, A., R. Li, P. A. Audano, D. Porubsky, M. R. Vollger, G. A. Logsdon, Consortium Human Genome Structural Variation, W. C. Warren, A. A. Pollen, M. J. P. Chaisson, and E. E. Eichler. 2019. 'Human-specific tandem repeat expansion and differential gene expression during primate evolution', Proc Nat1 Acad Sci U S A, 116: 23243-53.

Swinnen, B., W. Robberecht, and L. Van Den Bosch. 2020. 'RNA toxicity in non-coding repeat expansion disorders', EMBO J, 39: e101112.

Tantale, K., F. Mueller, A. Kozulic-Pirher, A. Lesne, J. M. Victor, M. C. Robert, S. Capozi, R. Chouaib, V. Backer, J. Mateos-Langerak, X. Darzacq, C. Zimmer, E. Basyuk, and E. Bertrand. 2016. 'A single-molecule view of transcription reveals convoys of RNA polymerases and multi-scale bursting', Nat Commun, 7: 12248.

Tassone, F., C. Iwahashi, and P. J. Hagerman. 2004. 'FMR1 RNA within the intranuclear inclusions of fragile X-associated tremor/ataxia syndrome (FXTAS)', RNA Biol, 1: $103-5$.

Todd, P. K., S. Y. Oh, A. Krans, F. He, C. Sellier, M. Frazer, A. J. Renoux, K. C. Chen, K. M. Scaglione, V. Basrur, K. Elenitoba-Johnson, J. P. Vonsattel, E. D. Louis, M. A. Sutton, J. P. Taylor, R. E. Mills, N. Charlet-Berguerand, and H. L. Paulson. 2013. ' CGG repeat-associated translation mediates neurodegeneration in fragile $\mathrm{X}$ tremor ataxia syndrome', Neuron, 78: 440-55.

Trottier, Y., Y. Lutz, G. Stevanin, G. Imbert, D. Devys, G. Cance1, F. Saudou, C. Weber, G. David, L. Tora, and et al. 1995. 'Polyglutamine expansion as a pathological epitope in Huntington's disease and four dominant cerebellar ataxias', Nature, 378: 403-6.

Tuduri, S., L. Crabbe, C. Conti, H. Tourriere, H. Holtgreve-Grez, A. Jauch, V. Pantesco, J. De Vos, A. Thomas, C. Theillet, Y. Pommier, J. Tazi, A. Coquelle, and P. Pasero. 2009. 'Topoisomerase I suppresses genomic instability by preventing interference between replication and transcription', Nat Cell Biol, 11: 1315-24.

Udan-Johns, M., R. Bengoechea, S. Be11, J. Shao, M. I. Diamond, H. L. True, C. C. Weihl, and R. H. Baloh. 2014. 'Prion-like nuclear aggregation of TDP-43 during heat shock is regulated by HSP40/70 chaperones', Hum Mol Genet, 23: 157-70.

Urbanek, M. 0., and W. J. Krzyzosiak. 2016. 'RNA FISH for detecting expanded repeats in human diseases', Methods, 98: 115-23.

Urbanek, M. 0., M. Michalak, and W. J. Krzyzosiak. 2017. '2D and 3D FISH of expanded repeat RNAs in human 1ymphoblasts', Methods, 120: 49-57.

Verma, A. K., E. Khan, S. K. Mishra, N. Jain, and A. Kumar. 2019. 'Piperine Modulates Protein 
Mediated Toxicity in Fragile X-Associated Tremor/Ataxia Syndrome through Interacting Expanded CGG Repeat ( $(\mathrm{CGG})$ (exp)) RNA', ACS Chem Neurosci, 10: 3778-88.

Wang, C., Y. Duan, G. Duan, Q. Wang, K. Zhang, X. Deng, B. Qian, J. Gu, Z. Ma, S. Zhang, L. Guo, C. Liu, and Y. Fang. 2020. 'Stress Induces Dynamic, Cytotoxicity-Antagonizing TDP-43 Nuclear Bodies via Paraspeckle LncRNA NEAT1-Mediated Liquid-Liquid Phase Separation', Mol Ce11, 79: 443-58 e7.

Westergard, T., K. McAvoy, K. Russe11, X. Wen, Y. Pang, B. Morris, P. Pasine1li, D. Trotti, and A. Haeusler. 2019. 'Repeat-associated non-AUG translation in C9orf72-ALS/FTD is driven by neuronal excitation and stress', EMBO Mol Med, 11.

Yamashita, R., Y. Suzuki, S. Sugano, and K. Nakai. 2005. 'Genome-wide analysis reveals strong correlation between $\mathrm{CpG}$ islands with nearby transcription start sites of genes and their tissue specificity', Gene, 350: 129-36.

Young, A. P., D. J. Jackson, and R. C. Wyeth. 2020. 'A technical review and guide to RNA fluorescence in situ hybridization', PeerJ, 8: e8806.

Yu, H., S. Lu, K. Gasior, D. Singh, S. Vazquez-Sanchez, 0. Tapia, D. Toprani, M. S. Beccari, J. R. Yates, 3rd, S. Da Cruz, J. M. Newby, M. Lafarga, A. S. Gladfelter, E. Villa, and D. W. Cleveland. 2020. 'HSP70 chaperones RNA-free TDP-43 into anisotropic intranuclear liquid spherical shells', Science.

Zhang, K., J. G. Daigle, K. M. Cunningham, A. N. Coyne, K. Ruan, J. C. Grima, K. E. Bowen, H. Wadhwa, P. Yang, F. Rigo, J. P. Taylor, A. D. Gitler, J. D. Rothstein, and T. E. Lloyd. 2018. 'Stress Granule Assembly Disrupts Nucleocytoplasmic Transport', Cell, 173: 958-71 e17.

Zhang, K., C. J. Donnelly, A. R. Haeusler, J. C. Grima, J. B. Machamer, P. Steinwald, E. L. Daley, S. J. Miller, K. M. Cunningham, S. Vidensky, S. Gupta, M. A. Thomas, I. Hong, S. L. Chiu, R. L. Huganir, L. W. Ostrow, M. J. Matunis, J. Wang, R. Sattler, T. E. Lloyd, and J. D. Rothstein. 2015. 'The C9orf72 repeat expansion disrupts nucleocytoplasmic transport', Nature, 525: 56-61.

Zu, T., B. Gibbens, N. S. Doty, M. Gomes-Pereira, A. Huguet, M. D. Stone, J. Margolis, M. Peterson, T. W. Markowski, M. A. Ingram, Z. Nan, C. Forster, W. C. Low, B. Schoser, N. V. Somia, H. B. Clark, S. Schmeche1, P. B. Bitterman, G. Gourdon, M. S. Swanson, M. Moseley, and L. P. Ranum. 2011. 'Non-ATG-initiated translation directed by microsatellite expansions', Proc Nat1 Acad Sci U S A, 108: 260-5. 